Article

\title{
A Comprehensive Evaluation of Salt Tolerance in Tomato (Var. Ailsa Craig): Responses of Physiological and Transcriptional Changes in RBOH's and ABA Biosynthesis and Signalling Genes
}

\author{
Abdul Raziq 1,2, Yu Wang 1,3, Atta Mohi Ud Din 1,4 , Jin Sun 1,3, Sheng Shu 1,3 and Shirong Guo 1,3,* \\ 1 Key Laboratory of Southern Vegetable Crop Genetic Improvement, Ministry of Agriculture, College of \\ Horticulture, Nanjing Agricultural University, Nanjing 210095, China; raziqbaloch867@gmail.com (A.R.); \\ ywang@njau.edu.cn (Y.W.); attajutt82@yahoo.com (A.M.U.D.); jinsun@njau.edu.cn (J.S.); \\ shusheng@njau.edu.cn (S.S.) \\ 2 Directorate of Vegetable Seed Production, Agriculture Research Institute, Village Aid Sariab, \\ Quetta 87300, Pakistan \\ 3 Suqian Academy of Protected Horticulture, Nanjing Agricultural University, Suqian 223800, China \\ 4 Key Laboratory of Crop Physiology Ecology and Production Management, Ministry of Agriculture, College of \\ Agriculture, Nanjing Agricultural University, Nanjing 210095, China \\ * Correspondence: srguo@njau.edu.cn
}

check for updates

Citation: Raziq, A.; Wang, Y.; Mohi Ud Din, A.; Sun, J.; Shu, S.; Guo, S. A Comprehensive Evaluation of Salt Tolerance in Tomato (Var. Ailsa Craig): Responses of Physiological and Transcriptional Changes in RBOH's and ABA Biosynthesis and Signalling Genes. Int. J. Mol. Sci. 2022, 23, 1603. https://doi.org/ $10.3390 /$ ijms 23031603

Academic Editors: Edward

E. Schmidt, Hozumi Motohashi and Anna Kipp

Received: 30 December 2021

Accepted: 26 January 2022

Published: 29 January 2022

Publisher's Note: MDPI stays neutral with regard to jurisdictional claims in published maps and institutional affiliations.

Copyright: (C) 2022 by the authors Licensee MDPI, Basel, Switzerland. This article is an open access article distributed under the terms and conditions of the Creative Commons Attribution (CC BY) license (https:// creativecommons.org/licenses/by/ $4.0 /)$.

\begin{abstract}
Salinity is a ubiquitous stressor, depleting osmotic potential and affecting the tomato seedlings' development and productivity. Considering this critical concern, we explored the salinity response in tomato seedlings by evaluating them under progressive salt stress duration $(0,3,6$, and 12 days). Intriguingly, besides the adverse effect of salt stress on tomato growth the findings exhibited a significant role of tomato antioxidative system, $\mathrm{RBOH}$ genes, ABA biosynthesis, and signaling transcription factor for establishing tolerance to salinity stress. For instance, the activities of enzymatic and non-enzymatic antioxidants continued to incline positively with the increased levels of reactive oxygen species $\left(\mathrm{O}_{2}^{\bullet-}, \mathrm{H}_{2} \mathrm{O}_{2}\right), \mathrm{MDA}$, and cellular damage, suggesting the scavenging capacity of tomato seedlings against salt stress. Notably, the $\mathrm{RBOH}$ transcription factors activated the hydrogen peroxide-mediated signalling pathway that induced the detoxification mechanisms in tomato seedlings. Consequently, the increased gene expression of antioxidant enzymes and the corresponding ratio of non-enzymatic antioxidants AsA-GSH suggested the modulation of antioxidants to survive the salt-induced oxidative stress. In addition, the endogenous ABA level was enhanced under salinity stress, indicating higher ABA biosynthesis and signalling gene expression. Subsequently, the upregulated transcript abundance of ABA biosynthesis and signalling-related genes suggested the ABA-mediated capacity of tomato seedlings to regulate homeostasis under salt stress. The current findings have revealed fascinating responses of the tomato to survive the salt stress periods, in order to improve the abiotic stress tolerance in tomato.
\end{abstract}

Keywords: tomato; ABA; RBOH; ROS; osmoprotectants; metabolites; antioxidant enzymes; reactive oxygen species; photosynthesis

\section{Introduction}

Salt stress is a major abiotic stress that adversely affects crop growth, development, quality, and yield [1,2]. High salinity affects plant cellular function by influencing uptake and assimilation of mineral ions, enzyme activity and photosynthetic function [3-5]. The higher accumulation of $\mathrm{Na}^{+}$ions induces ionic and osmotic stress in plants, which causes alteration in plants structural and functional stability [6,7]. High salt concentrations in plants can cause an imbalance between production and scavenging of reactive oxygen species (ROS) such as superoxide anion $\left(\mathrm{O}_{2}{ }^{\bullet-}\right)$, hydrogen peroxide $\left(\mathrm{H}_{2} \mathrm{O}_{2}\right)$ and hydroxyl 
radicals $\left(\mathrm{OH}^{\bullet}\right)$, particularly in chloroplasts and mitochondria, and induce hyperosmotic stress that can lead to oxidative damage $[8,9]$. In addition, the excess of salts reduces growth, mainly by reducing cell expansion in root tips and younger leaves thereby promoting premature senescence or programmed cell death $[10,11]$.

Plants have developed various physiological, biochemical, and molecular processes to regulate salt stress's adverse effects. Usually, plants endure sub-optimal environments by adopting a set of mechanisms that collectively respond against the stressful environment either by acclimation, escape, or detoxification [7,12]. Among them, one such possible mechanism is the accumulation of osmoprotectants, such as amino acids (proline) and non-structural sugars to maintain the osmotic balance under the prevailing stress conditions $[13,14]$. Besides this, plants also have an antioxidative defense system that contains enzymatic antioxidants (Superoxide dismutase (SOD), peroxidase (POD), catalase (CAT), ascorbate peroxidase (APX), Glutathione peroxidase (GPX), glutathione reductase (GR)) and non-enzymatic antioxidants (Ascorbate(AsA) and Glutathione (GSH)) that helps in scavenging the stress-induced reactive oxygen species (ROSs) [15,16].

ROS also acts as a multipurpose signal to initiate a series of subsequent defense signalling under various environmental stresses, including high salinity, drought, pathogenic infection and heat stress [17]. Particularly, the NADPH oxidase/respiratory burst oxidase homolog (RBOHs) transcription factors are essential in regulating ROS generation and subsequent signalling events for salinity adaptation. Previous investigations revealed that $\mathrm{RBOH}$ are involved in different signalling pathways that regulate root hair growth, stomatal closure, pollen-stigma interactions, defense responses to pathogens, and acclimation to abiotic stresses [18-20]. Notably, tomato consists of eight RBOHs that are involved in stomatal movements through different phytohormones. For instance, RBOH1 gene is linked to Abscisic acid (ABA)-mediated salinity tolerance in tomatoes. Accumulation of ABA usually increases transcript levels of $R B O H 1$ and other defense-related genes resulting in elevated apoplastic $\mathrm{H}_{2} \mathrm{O}_{2}$ collection, increasing the activity of NADPH oxidase and antioxidant enzymes in tomatoes [21]. In addition to their importance in biotic and abiotic responses, $\mathrm{RBOH}$ genes are also shown to play critical roles in plant growth and development associated with hormone signalling [22].

$\mathrm{ABA}$ is a primary plant hormone involved in salt stress response regulation, including stomatal closure, ion homeostasis, salt stress-responsive gene expression, and metabolic changes [23]. ABA functions as a central integrator that links and reprograms the complex developmental process under salt stress and activates adaptive signalling cascades in plants [24]. Under stress conditions, plants induce the production of ABA biosynthesis genes, such as Nine-Cis-Epoxycarotenoid Dioxygenases (NCEDs) and ABA Deficient (ABAs). The ABA receptors then perceive ABA Pyrabactin Resistance/Pyrabactin Resistance Like (PYR/PYL), which induce phosphorylation activity of the ABA-dependent Sucrose Non-Fermenting Related Protein Kinases (SnRKs) family, and the activation of ABA-dependent transcriptional network involved in ionic and osmotic adjustments in response to salt stress [25-27].

Tomato (Solanum Lycopersicum), a widely used vegetable crop throughout the world, is a rich source of antioxidant molecules such as carotenoids, vitamins E and C, ascorbic acid and phenolic compounds, mainly flavonoids. However, salt stress imposes several negative effects on the germination, growth, biomass accumulation and yield of tomatoes [11]. Keeping in view the increasing salinity concerns and global importance of tomato crop, this study was designed with an objective to demonstrate the role of the tomato antioxidative system, $\mathrm{RBOH}$ genes, ABA biosynthesis and signaling transcription factor under 12 days long salt stress to provide the basis for future studies regarding the improved salinity tolerance of tomato crops. 


\section{Results}

\subsection{Salt Stress Affects Morphological Indices and Pigment Contents of Tomato Seedlings}

Salt stress significantly affected the growth rate of tomatoes as depicted by the linear decline in pigment contents and the seedling vigour. Compared to control, the contents of Chl-a, Chl-b, Total Chlorophyll and Carotenoids contents decreased by $57.11 \%, 41.47 \%$, $51.14 \%$ and $15.75 \%$, respectively (Figure 1B-E). Consistently, the tomato seedlings' morphological indices, including biomass accumulation stem diameter and plant height, were also severely affected by the increasing salt stress duration as depicted by the significantly declining seedling index (SI) value and root shoot ratio. The SI value of seedlings decreased by $44.41 \%, 63.96 \%, 76.53 \%$ after 3,6 and 12 days of salt stress, respectively (Figure $1 \mathrm{~A}$ ).

(A)

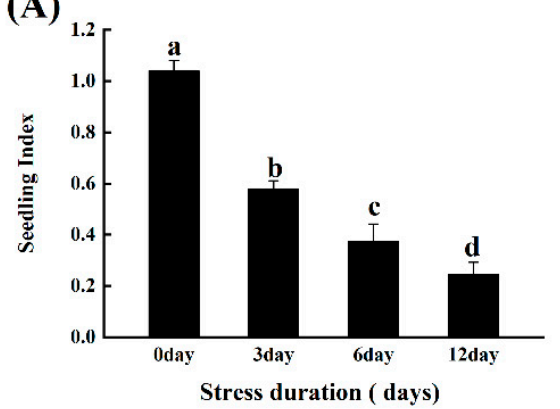

(D)

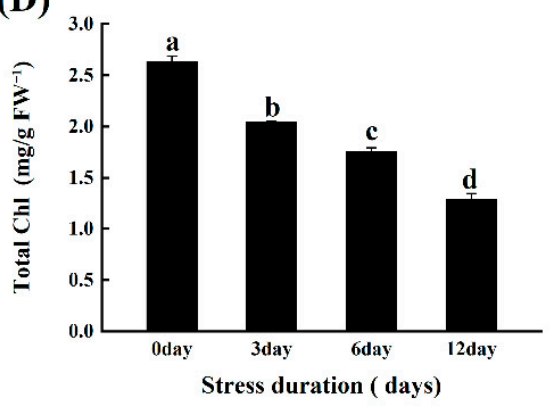

(B)

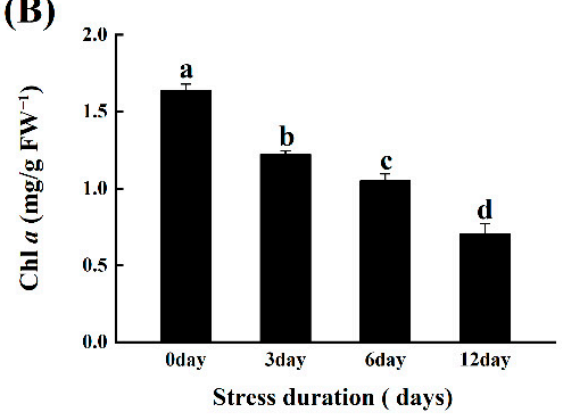

(E)

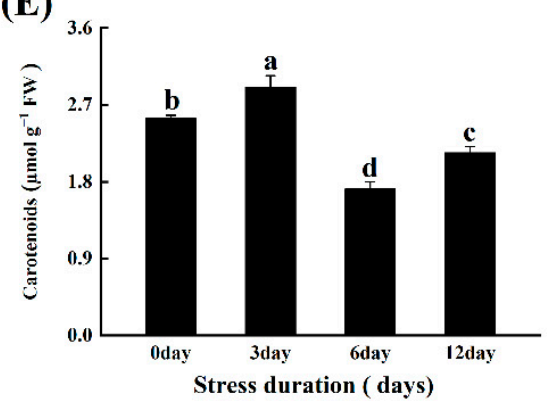

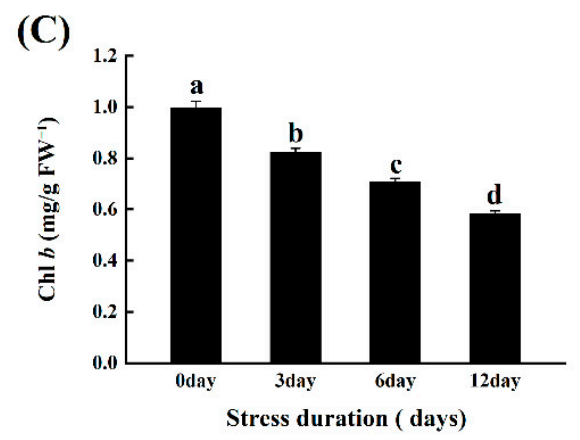

Figure 1. Effects of salt stress on (A) seedling index; (B) Chla; (C) Chlb; (D) Total Chl and (E) Carotenoids in leaves of tomato seedlings grown for 12 days under control and salt stress. Values are mean $\pm \mathrm{SD}$ (Standard Deviation) of three replications. Different letters indicate significant difference at $p \leq 0.05$ (Tukey's HSD test).

\subsection{Salt Stress Alters the Plant-Water Relations and Osmotic Potential of Tomato Seedlings}

The impact of salinity on the plant-water relationship was calculated by comparing the water potential $(\Psi \mathrm{w})$, osmotic potential $(\Psi \mathrm{s})$, turgor potential $(\Psi \mathrm{p})$ and osmotic adjustments (OA) between the control and salt treatments. As the salt stress duration increased, the values of $\Psi_{\mathrm{w}}$ and $\Psi_{\mathrm{s}}$ became more negative. Compared to control, the value of $\Psi \mathrm{w}$ and $\Psi$ s significantly reached up to $-111.24 \%$ and $-290 \%$ after 12 days of salt stress (Figure 2 ). Simultaneously, compared to control, the value of $\Psi p$ increased up to $74.26 \%$ after the 12 days of salt stress (Figure $2 \mathrm{~A}-\mathrm{C}$ ). Consistent with the alterations in $\Psi \mathrm{w}, \Psi$ s and $\Psi$ p, salt stress-induced significant (92\%) osmotic adjustments in tomato seedlings. Furthermore, the relative water content was decreased up to $63.33 \%$ under salt stress duration (Figure 2E). 


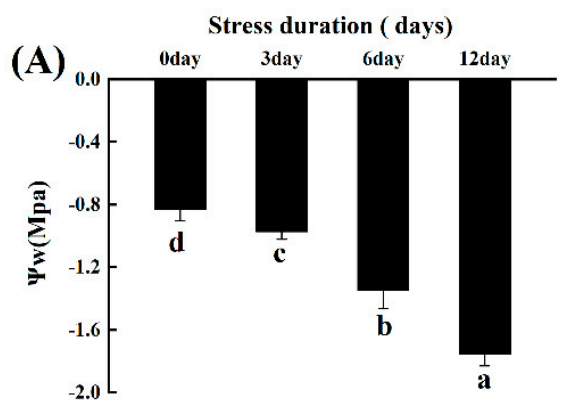

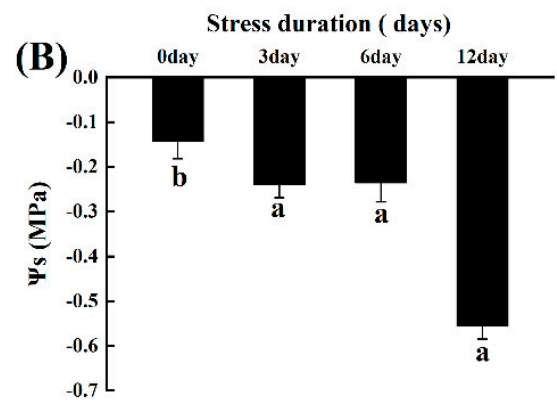

(E)

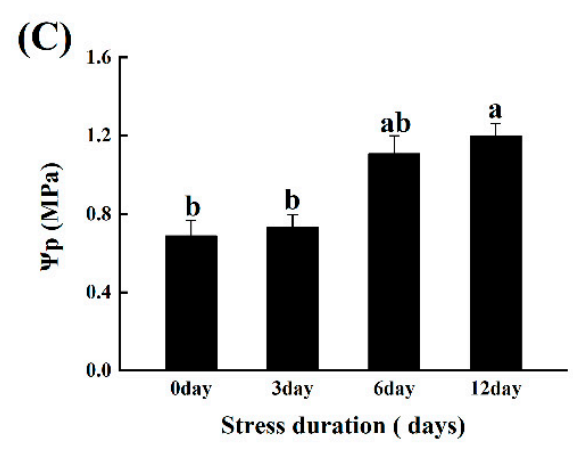

(D)

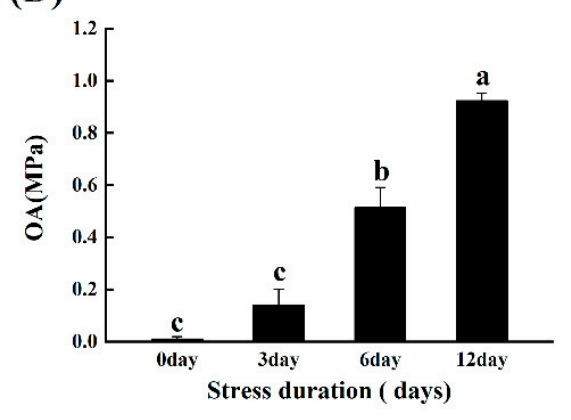

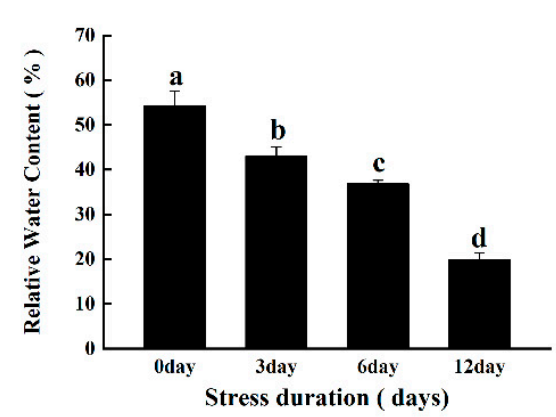

Figure 2. Effects of salt stress on (A) water potential ( $\Psi$ w); (B) osmotic potential ( $\Psi$ s); (C) turgor potential ( $\Psi \mathrm{p}$ ); (D) osmotic adjustments (OA) and (E) relative water content (RWC) in leaves of tomato seedlings grown for 12 days under control and salt stress. Values are mean \pm SD (Standard Deviation) of three replications. Different letters indicate significant differences at $p \leq 0.05$ (Tukey's HSD test).

\subsection{Salt Stress Changes the Protein, Soluble Sugars, and Proline Content in Tomato Seedlings}

To assess the osmoprotective potential of tomato plants after salt stress, we measured the levels of two significant osmolytes, soluble sugars and proteins, in the roots and leaves of tomato seedlings. Salt stress induced the significant accumulation of proline and soluble sugars in the leaves and roots of tomato seedlings. Compared to control, the quantity of soluble sugars and proline increased by $93.07 \%$ and $79.77 \%$ in roots, and $56.02 \%$ and $71.00 \%$ in leaves, after 12 days of salt stress, respectively (Figure 3B,C,E,F). However, the salt stress negatively affected the protein contents, and a significant decline $(65.09 \%$ and $92.43 \%)$ was observed in root and leaves after 12 days of salt stress, respectively (Figure 3A,D). 

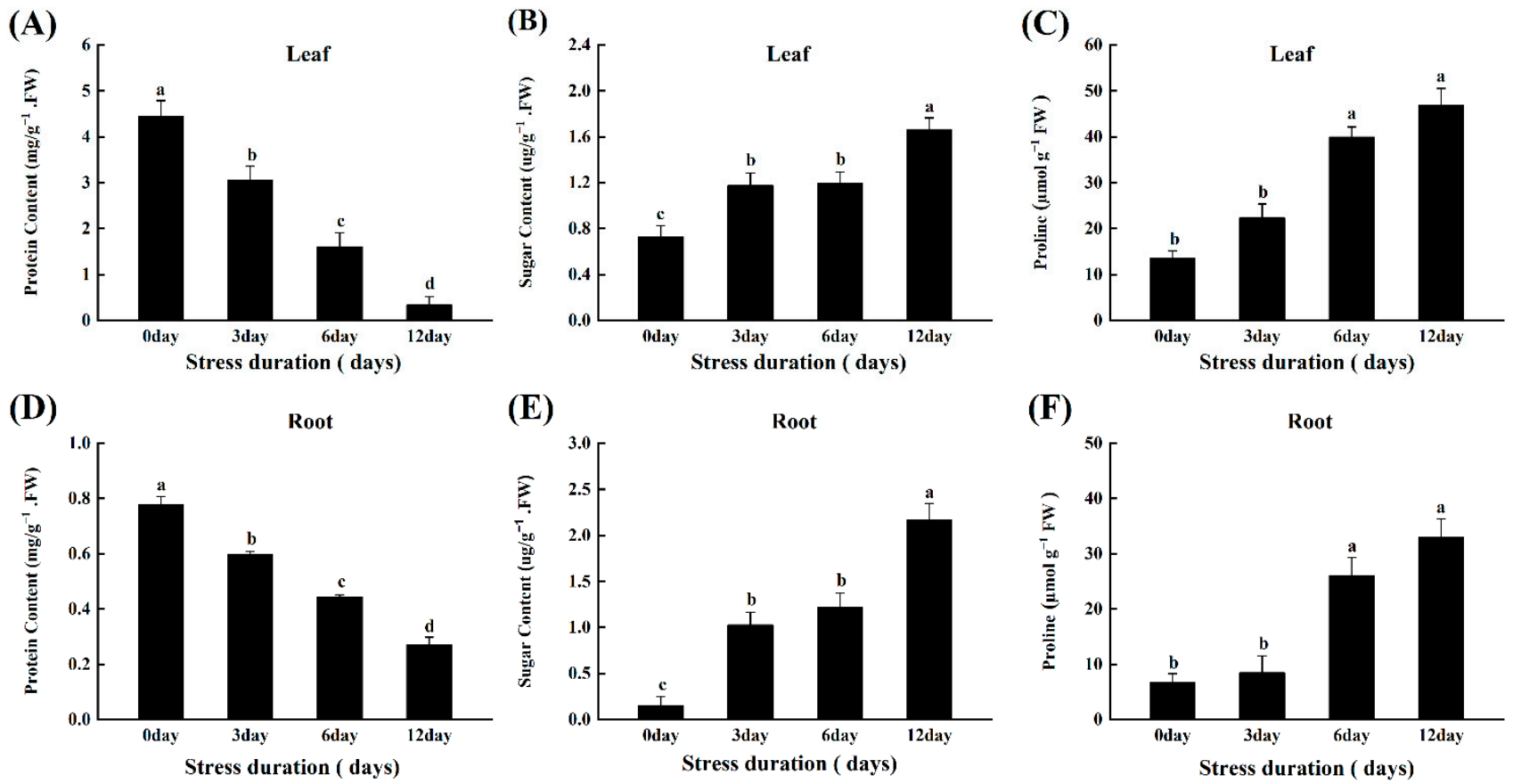

Figure 3. Effects of salt stress on protein content $(\mathbf{A}, \mathbf{D})$; Sugar content $(\mathbf{B}, \mathbf{E})$ and Proline $(\mathbf{C}, \mathbf{F})$ in leaves and roots of tomato seedlings grown for 12 days under control and salt stress. Values are mean \pm SD (Standard Deviation) of three replications. Different letters indicate significant difference at $p \leq 0.05$ (Tukey's HSD test).

\subsection{Salt Stress Disturbed the Ionic Ratios and the Contents of Macro and Micronutrients in Tomato Seedlings}

Salt stress significantly changed the nutrient contents of macro and micronutrients in both leaves and roots. Compared with control, the contents of phosphorus (P), iron (Fe), manganese $(\mathrm{Mn})$, magnesium $(\mathrm{Mg})$, copper $(\mathrm{Cu})$ and potassium $\left(\mathrm{K}^{+}\right)$decreased significantly while the contents of zinc $(\mathrm{Zn})$ and calcium $(\mathrm{Ca})$ increased significantly under the salt stress (Tables 1 and 2). P content decreased by 30.43\% and 51.41\%, Fe contents decreased by $30.36 \%$ and $54.27 \%$, Mn contents decreased by $83.33 \%$ and $40.28 \%$, Mg contents decreased by $35.97 \%$ and $39.40 \%$ and $\mathrm{K}^{+}$decreased by $27.35 \%$ and $28.87 \%$ in leaves and roots after 12 days of salt stress, respectively. However, the $\mathrm{Cu}, \mathrm{Ca}^{2+}$ and $\mathrm{Na}^{+}$contents increased by $119.77 \%$ and $35.84 \%, 124.04 \%$ and $71.82 \%$, and $36.86 \%$ and $87.85 \%$ in leaves and roots after the 12 days of salt stress, respectively. Overall, the impact of salt stress was most obvious in the roots of salt-treated tomato seedlings than the leaves.

Table 1. Interactive effect of $\mathrm{NaCl}$ treatments on the macro and micronutrients uptake in leaves of tomato seedlings after 12 days under control and salanity stress.

\begin{tabular}{|c|c|c|c|c|c|c|c|c|c|}
\hline Treatments & $\mathbf{P}$ & Zn & $\mathrm{Fe}$ & Mn & Mg & $\mathrm{Ca}^{2+}$ & $\mathrm{Cu}$ & $\mathrm{Na}^{+}$ & $\mathrm{K}^{+}$ \\
\hline 0 day & $6.62 \pm 0.74 \mathrm{a}$ & $0.03 \pm 0.00 \mathrm{~b}$ & $1.46 \pm 2.12 \mathrm{a}$ & $0.46 \pm 0.08 \mathrm{a}$ & $3.16 \pm 0.09 a$ & $0.67 \pm 0.03 b$ & $4.61 \pm 0.23 \mathrm{a}$ & $0.26 \pm 0.01 \mathrm{~d}$ & $22.78 \pm 2.44 \mathrm{a}$ \\
\hline 3 day & $5.46 \pm 0.08 b$ & $0.04 \pm 0.00 \mathrm{~b}$ & $1.34 \pm 5.75 \mathrm{ab}$ & $0.29 \pm 0.01 b$ & $2.58 \pm 0.08 \mathrm{ab}$ & $0.84 \pm 0.10 \mathrm{~b}$ & $5.54 \pm 0.69 \mathrm{ab}$ & $0.30 \pm 0.01 c$ & $18.66 \pm 0.34 b$ \\
\hline 6 day & $5.16 \pm 0.28 b$ & $0.04 \pm 0.00 \mathrm{~b}$ & $1.23 \pm 8.09 \mathrm{~b}$ & $0.19 \pm 0.00 \mathrm{c}$ & $2.24 \pm 0.07 \mathrm{~b}$ & $3.78 \pm 0.02 \mathrm{~b}$ & $6.99 \pm 0.66 \mathrm{ab}$ & $0.31 \pm 0.01 \mathrm{~b}$ & $17.64 \pm 0.58 \mathrm{~b}$ \\
\hline 12 day & $4.60 \pm 0.08 \mathrm{~b}$ & $0.05 \pm 0.01 \mathrm{a}$ & $0.101 \pm 12.90 c$ & $0.08 \pm 0.01 \mathrm{~d}$ & $2.02 \pm 0.02 b$ & $5.96 \pm 0.47 \mathrm{a}$ & $10.13 \pm 4.00 \mathrm{~b}$ & $0.35 \pm 0.01 \mathrm{a}$ & $16.55 \pm 0.55 b$ \\
\hline
\end{tabular}

Data represent the mean and standard deviation (SD) of three replications. Different letters indicate significant differences according to 'Tukey's HSD test at $p \leq 0.05$. 
Table 2. Interactive effect of $\mathrm{NaCl}$ treatments on the macro and micro nutrients uptake in roots of tomato seedlings after 12 day under control and salanity stress.

\begin{tabular}{|c|c|c|c|c|c|c|c|c|c|}
\hline Treatments & $\mathbf{P}$ & $\mathrm{Zn}$ & $\mathrm{Fe}$ & Mn & $\mathrm{Mg}$ & $\mathrm{Ca}^{2+}$ & $\mathrm{Cu}$ & $\mathrm{Na}^{+}$ & $\mathrm{K}^{+}$ \\
\hline 0 day & $9.67 \pm 0.27 \mathrm{a}$ & $0.01 \pm 0.01 \mathrm{~d}$ & $0.19 \pm 0.01 \mathrm{a}$ & $1.15 \pm 0.12 \mathrm{a}$ & $4.03 \pm 0.39 a$ & $1.79 \pm 0.04 c$ & $6.16 \pm 0.52 c$ & $0.25 \pm 0.01 \mathrm{~d}$ & $28.41 \pm 1.28 \mathrm{a}$ \\
\hline 3 day & $8.68 \pm 0.47 b$ & $0.01 \pm 0.01 \mathrm{c}$ & $0.15 \pm 0.01 \mathrm{~b}$ & $1.29 \pm 0.03 b$ & $3.65 \pm 0.02 \mathrm{a}$ & $2.06 \pm 0.17 c$ & $6.79 \pm 0.10 \mathrm{bc}$ & $0.30 \pm 0.01 c$ & $25.31 \pm 0.16 b$ \\
\hline 6 day & $5.53 \pm 0.09 \mathrm{c}$ & $0.03 \pm 0.01 \mathrm{~b}$ & $0.12 \pm 0.01 \mathrm{c}$ & $1.09 \pm 0.01 \mathrm{c}$ & $2.87 \pm 0.06 \mathrm{~b}$ & $2.39 \pm 0.06 \mathrm{~b}$ & $7.35 \pm 0.40 \mathrm{~b}$ & $0.42 \pm 0.01 \mathrm{~b}$ & $22.21 \pm 0.21 \mathrm{c}$ \\
\hline 12 day & $4.70 \pm 0.34 \mathrm{~d}$ & $0.04 \pm 0.01 \mathrm{a}$ & $0.09 \pm 0.01 \mathrm{~d}$ & $0.90 \pm 0.08 \mathrm{~d}$ & $2.44 \pm 0.17 b$ & $3.08 \pm 0.21 \mathrm{a}$ & $8.37 \pm 0.33 a$ & $0.47 \pm 0.02 \mathrm{a}$ & $20.21 \pm 0.89 \mathrm{~d}$ \\
\hline
\end{tabular}

Data represent the mean and standard deviation (SD) of three replications. Different letters indicate significant differences according to 'Tukey's HSD test at $p \leq 0.05$.

\subsection{Salt Stress Instigates ROS Accumulation, Lipid Peroxidation and Oxidative Damage in Tomato Seedlings}

The oxidative stress induced by the progressive salinity was estimated by calculating the accumulation of $\mathrm{H}_{2} \mathrm{O}_{2}$ and $\mathrm{O}_{2}{ }^{\bullet-}$ in the leaves and roots of tomato seedlings. A significant linear increase was observed in the amounts of $\mathrm{H}_{2} \mathrm{O}_{2}$ and $\mathrm{O}_{2}{ }^{-}{ }^{-}$with increasing duration of salt stress in both leaves and roots. $\mathrm{H}_{2} \mathrm{O}_{2}$ and $\mathrm{O}_{2}{ }^{\bullet-}$ levels increased by $46.31 \%$ and $96.40 \%$ in roots, and $57.18 \%$ and $87.84 \%$ in leaves, after 12 days of salt stress, respectively (Figure 4A,B,E,F). Furthermore, we confirmed the oxidative damage induced by salt stress in roots by root activity analysis (TTC staining) and leaves by MDA content and membrane stability index (MSI). Consistent with the ROS accumulation, the MDA contents increased significantly with increasing salt stress compared to control.

(A)

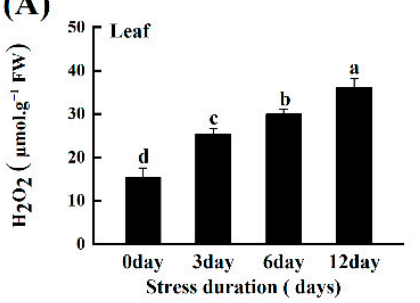

(E)

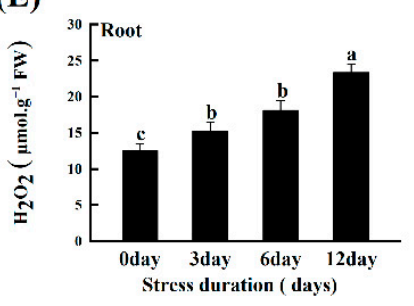

(B)

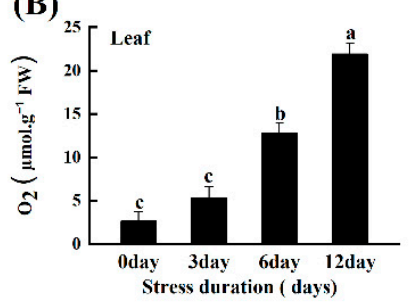

(F)

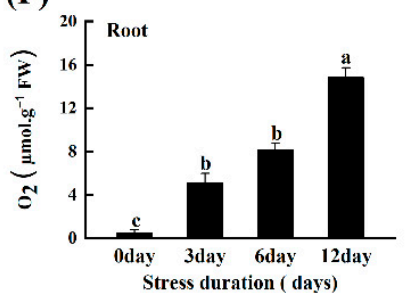

(C)

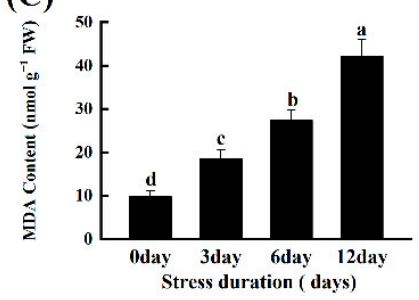

(G)

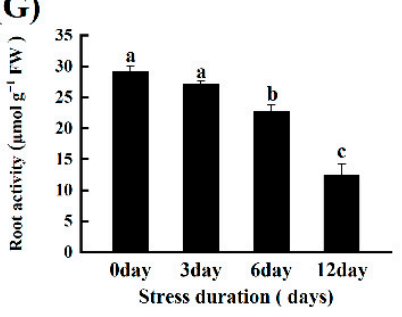

(D)

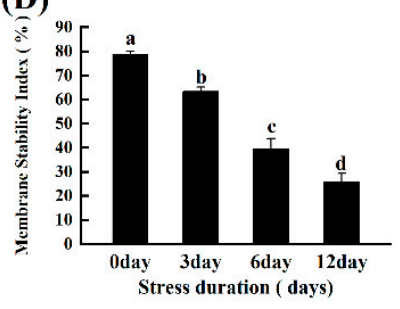

Figure 4. Effects of salt stress on $\mathrm{H}_{2} \mathrm{O}_{2}$ in leaves; roots $(\mathbf{A}, \mathbf{E}) ; \mathrm{O}_{2}{ }^{--}$in leaves; roots $(\mathbf{B}, \mathbf{F})$; malondialdehyde (MDA) (C); membrane stability index MSI (D); and root activity (G) of tomato seedlings grown for 12 days under control and salt stress. Values are mean \pm SD (Standard Deviation) of three replications. Different letters indicate significant differences at $p \leq 0.05$ (Tukey's HSD test).

Similarly, the increasing lipid peroxidation and oxidative stress seriously damaged the membrane stability, as depicted by the $67.19 \%$ decline in MSI, after 12 days of salt stress (Figure 4C,D). Also, the root activity markedly declined by $57.23 \%$ compared to the control after 12 days of salt stress (Figure 4G). We further checked the gas exchange parameters and the photochemical efficiency, by carefully expanding the wilted leaf with hand, to assess the photosynthetic inhibition under salt-induced oxidative stress and found a linear decrease with increased salt stress duration (Supplementary Table S1).

\subsection{Salt Stress Activates the ROS Scavenging Mechanism in Tomato Seedlings}

The capacity of tomato seedlings to counter the increasing accumulation of ROS to protect the cells from further oxidative damage under salt stress was evaluated by measuring the activities of major enzymatic and non-enzymatic antioxidants. Generally, salt stress triggered the activities of all the studied antioxidant enzymes to counter the production 
of excessive ROS. However, after an initial increase (128.47\% and $405.55 \%)$ up to 6 days compared to control, the activity of SOD and CAT decreased significantly after 12 days of salt stress. Compared to control, the plants after 12 days of salt stress had $472.72 \%$, $321.12 \%, 62.00 \%, 166.68 \%, 62.03 \%$ and $176.67 \%$ more activities of POD, APX, GR, MDHAR, DHAR and MDAR, respectively (Figure 5A-H). We further verified the response of antioxidant enzymes by checking the relative expression levels of genes encoding antioxidant enzymes. The gene expression level consistently showed a similar trend and confirmed the salt-stress induced upregulation in the gene expression level of antioxidant enzymes. The genes expression levels of leaves and roots revealed the upregulation in activities of SOD (1.73, 2.78-fold), POD (5.69, 2.27-fold), CAT (2.12, 2.50-fold), APX (2.62, 4.01-fold), GR (4.80, 2.31-fold), MDHAR (4.09, 4.65-fold), and DHAR (2.99, 7.75-fold) after 12 days of salt stress, respectively as compared to control (Figure 6A,B).
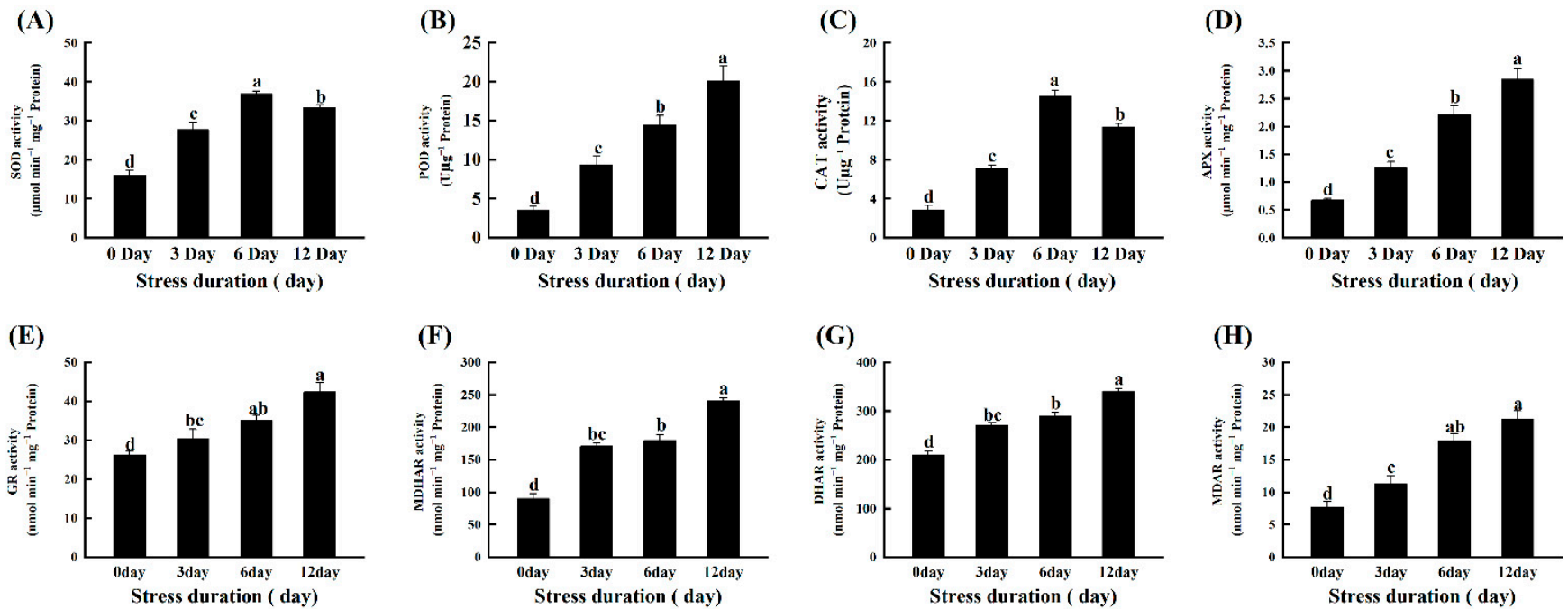

Figure 5. Effects of salt stress on antioxidant enzymes (A) superoxide dismutase SOD; (B) peroxidase POD; (C) catalase CAT; (D) ascorbate peroxidase APX; (E) glutathione reductase GR; (F) monodehydroascorbate reductase MDHAR; $(\mathbf{G})$ dehydroascorbate reductase DHAR; (H) MDAR; in tomato leaves seedlings grown for 12 days under control and salt stress. Values are mean \pm SD (Standard Deviation) of three replications. Different letters indicate significant differences at $p \leq 0.05$ (Tukey's HSD test).

Similar to enzymatic antioxidants, salt stress also induced alterations in the contents of non-enzymatic antioxidants, namely AsA, DHA, GSH and GSSG, and their ratios. The contents of AsA increased significantly by $2.13,179.48$ and $554.13 \%$, while DHA content decreased by 16.05, 17.99 and $151.25 \%$ after 3, 6 and 12 days of salt stress (Figure 6A,B). Consequently, the ratio of AsA/DHA increased markedly with the increasing duration of salt stress. Similarly, the contents of GSH, GSSH and their ratios also showed a significantly increasing trend. GSH content increased by 10,25 and $45 \%$, while GSH content increased by $81.81 \%, 113.33$ and $175.86 \%$, compared to control after 3,6 and 12 days of salt stress, respectively (Figure $7 \mathrm{~A}, \mathrm{~B})$. 


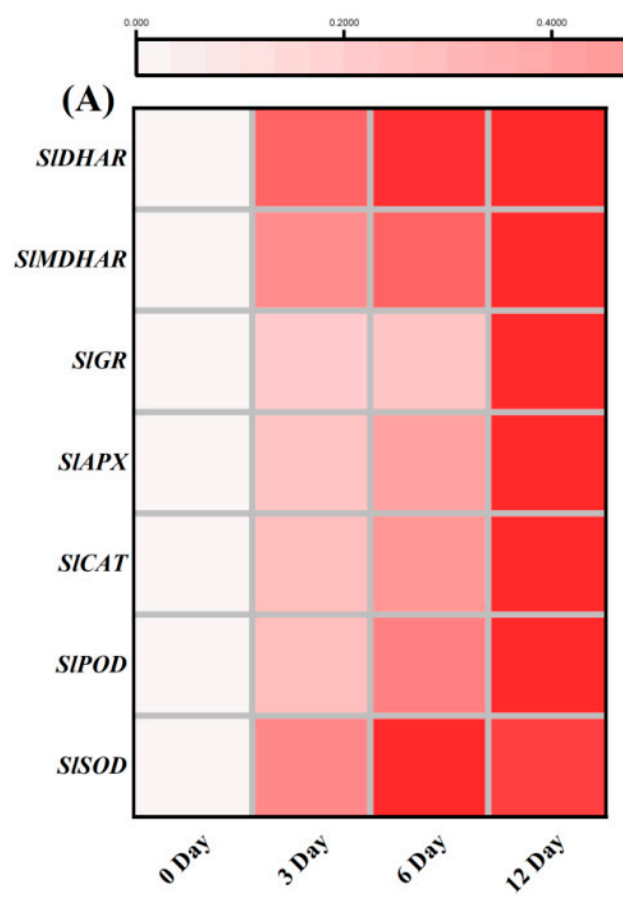

Stress duration (day)
(B)

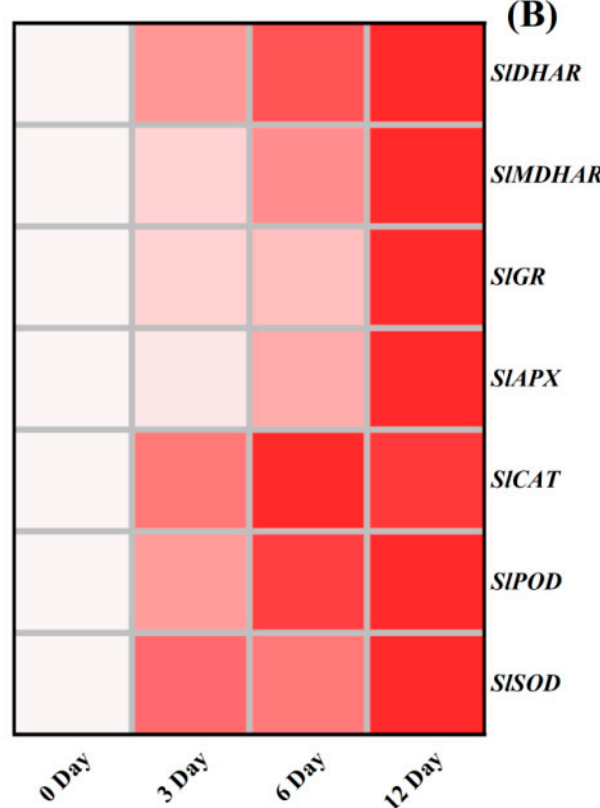

Stress duration (day)

Figure 6. Heatmap of antioxidant enzymes related genes in tomato (A) leaves and roots (B) after 12 day of salt treatment. The scale $\left(\log ^{2}\right.$ of the mean values after normalization; $\left.n=3\right)$ shows the increase in relative concentrations from white to red color, compared to control $(0 \mathrm{~h})$.

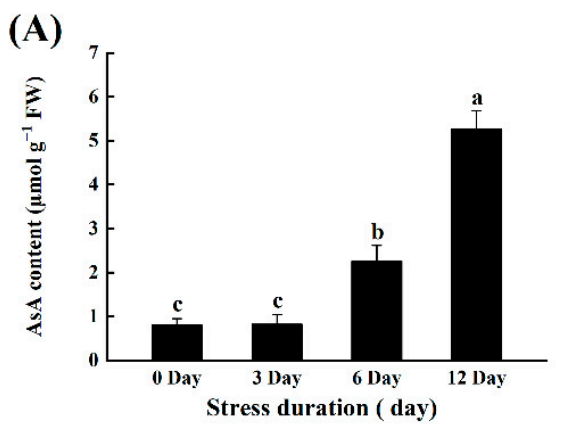

(D)

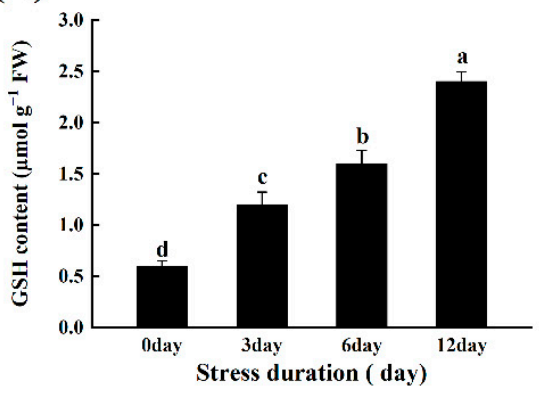

(B)

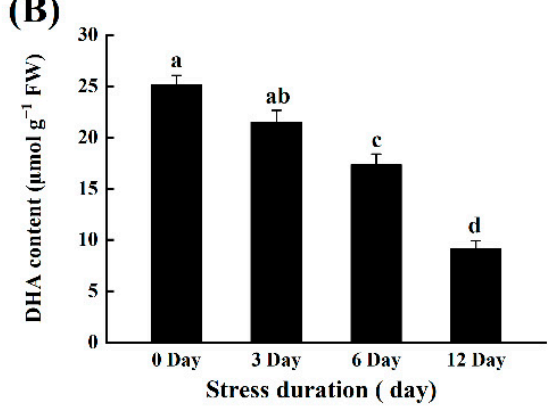

(E)

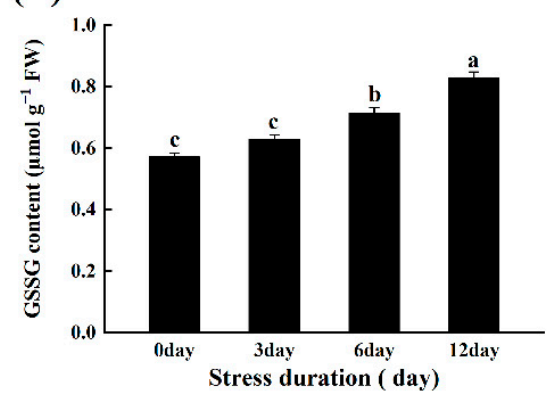

(C)

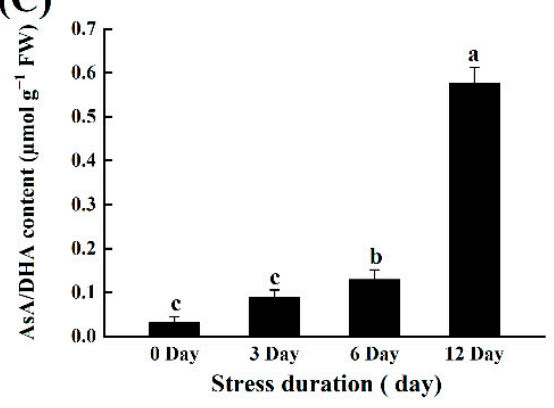

(F)

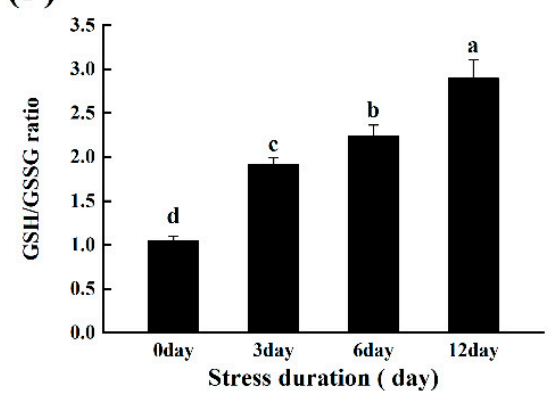

Figure 7. Effects of salt stress on non- antioxidant enzymes (A) Ascorbic acid AsA; (B) DHA; (C) AsA/DHA; (D) glutathione GSH; (E) GSSG; and (F) GSH/GSSG in tomato leaves seedlings grown for 12 days under control and salt stress. Values are mean \pm SD (Standard Deviation) of three replications. Different letters indicate significant differences at $p \leq 0.05$ (Tukey's HSD test).

2.7. Salt Stress Enhanced the Activation of Polyamines Metabolism Enzymes in Tomato Seedlings

Under salt stress, the activities of three major polyamine metabolism-related enzymes, $\mathrm{ADC}, \mathrm{DAO}$, and $\mathrm{PAO}$, were measured in tomato leaves. The findings revealed that in- 
creasing the duration of salt stress significantly increased PA metabolism enzymes' activity. The activities of two biosynthesizing enzymes, ADC and DAO, and catabolizing enzymes (PAO), increased by $243.42 \%, 205.00 \%$, and $222.00 \%$, respectively, when compared to the control (Figure 8A-C).

(A)

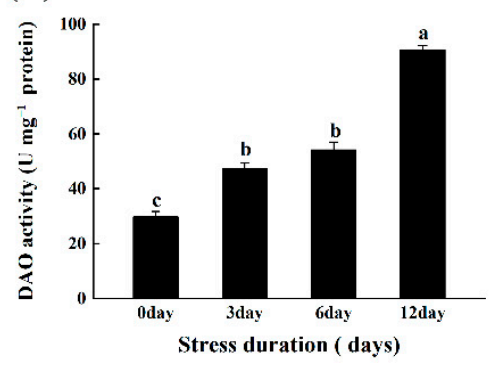

(B)

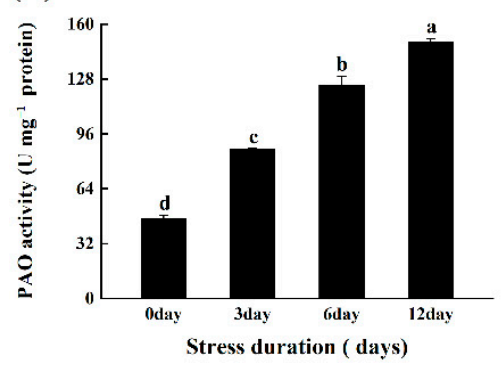

(C)

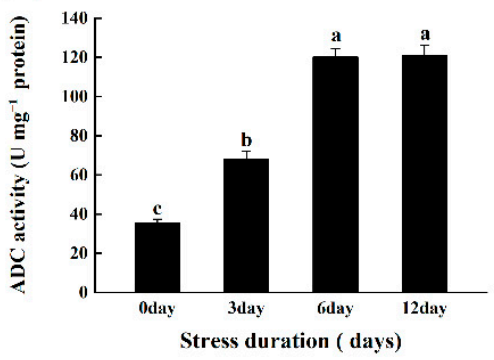

Figure 8. Effects of salt stress on (A) Diamine oxidase (ADC); (B) polyamine oxidase (PAO); and (C) Arginine decarboxylase (ADC) in tomato leaves grown for 12 days under control and salt stress. Values are mean \pm SD (Standard Deviation) of three replications. Different letters indicate significant differences at $p \leq 0.05$ (Tukey's HSD test).

\subsection{Salt Stress Upregulated Expression of Antioxidant, RBOHs and ABA Biosynthesis and} Signalling Related Genes in Tomato Seedlings

The transcripts abundance of various RBOHs related transcription factors was analyzed through qRT-PCR analysis. The results showed that 12 days of salt stress caused significant up-regulation of SIRBOH1, SlRBOH-A, SlRBOH-D, SIRBOH-E, and SIRBOH-F in the leaves, and SIRBOH1, SIRBOH-A and SIRBOH-D in the roots of tomato seedlings, as compared to the respective control plants. Interestingly the transcription level of $R B O H-H$ in leaves, $\mathrm{RBOH}-\mathrm{E}, \mathrm{RBOH}-\mathrm{F}$ and $\mathrm{RBOH}-\mathrm{H}$ in roots did not show significant variations in their expression levels during the early days (three days in leaves, six days in roots) of salt stress (Figure 9A,B).

In tomato seedlings under salt stress, the $\mathrm{ABA}$ content increased with the increasing duration of the salt stress and the highest $\mathrm{ABA}$ contents in both leaves and roots was noticed after 12 days of salt stress treatment (Figure 10A,B).

Therefore, we further analyzed the expression of ABA biosynthesis and signaling genes. Under salt stress, the transcription levels of ABA biosynthesis and signalling genes showed higher expression levels than control. For instance, salt stress upregulated the expression of ABA biosynthesis genes including SIZEP, SINCED1, SINCED3, SINCED5, SIAAO3, SlABI3 and SIABI5 in both leaves and roots, as compared to the control (Figure 11A,B).

Similarly, the ABA signaling genes, SISnRK2.2, SISnRK2.3, SISnRK2.6, SlPYL4, SlPYL8, SIABF4 and SIDREB2 also showed significantly higher transcript levels in leaves and roots in response to salt stress. Taken together, it suggested that the plants tried to counter the damage via enhanced signalling and biosynthesis of ABA (Figure 12A,B). 


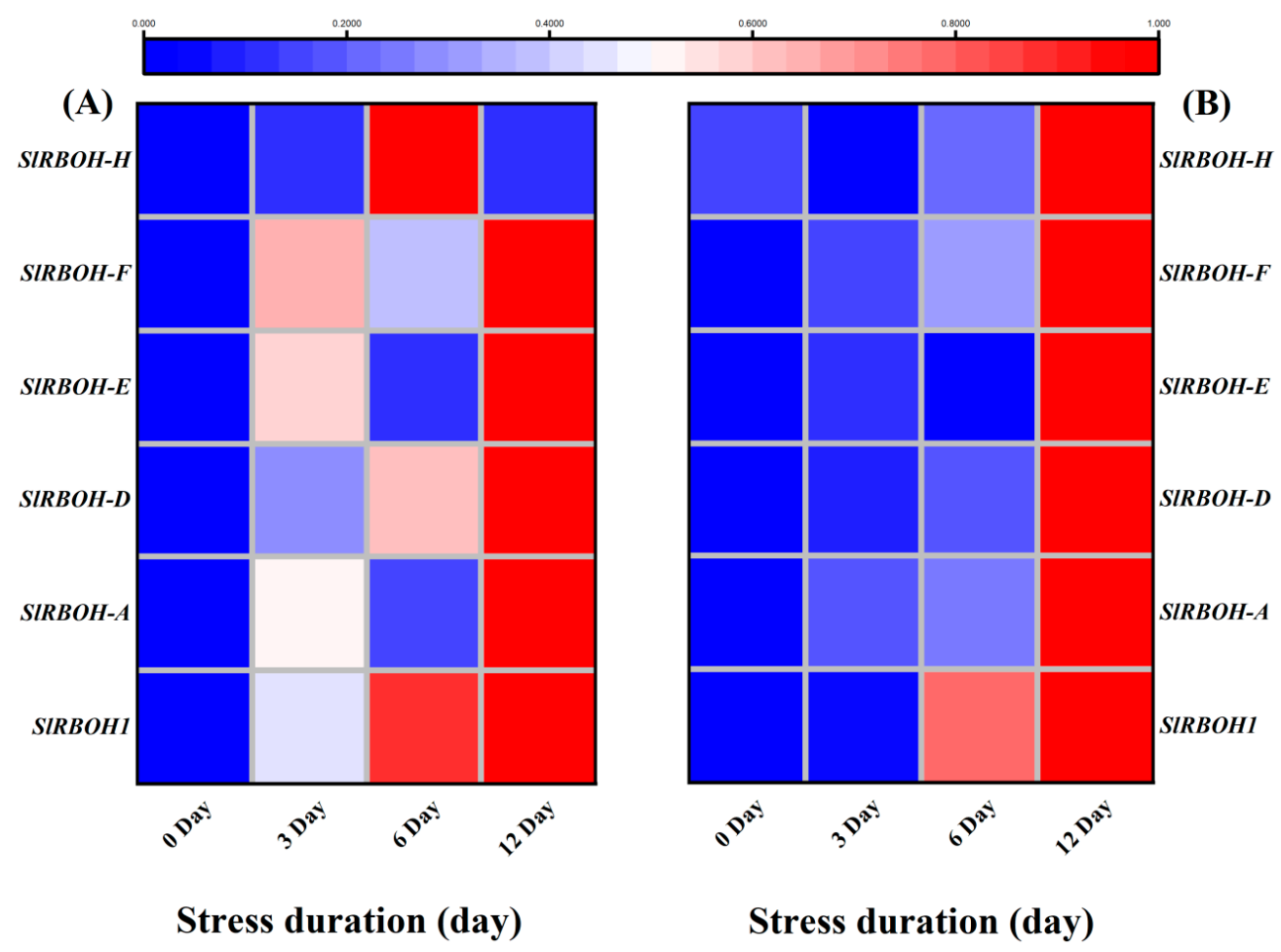

Figure 9. Heatmap of selected genes-related RBOHs (respiratory burst oxidase homolog proteins). The relative expression level was quantified from tomato (A) Leaves; (B) roots after 12days of salt treatment. The scale ( $\log ^{2}$ of the mean values after normalization; $n=3$ ) shows the increase in relative concentrations from blue to red color, compared to control $(0 \mathrm{~h})$.

(A)

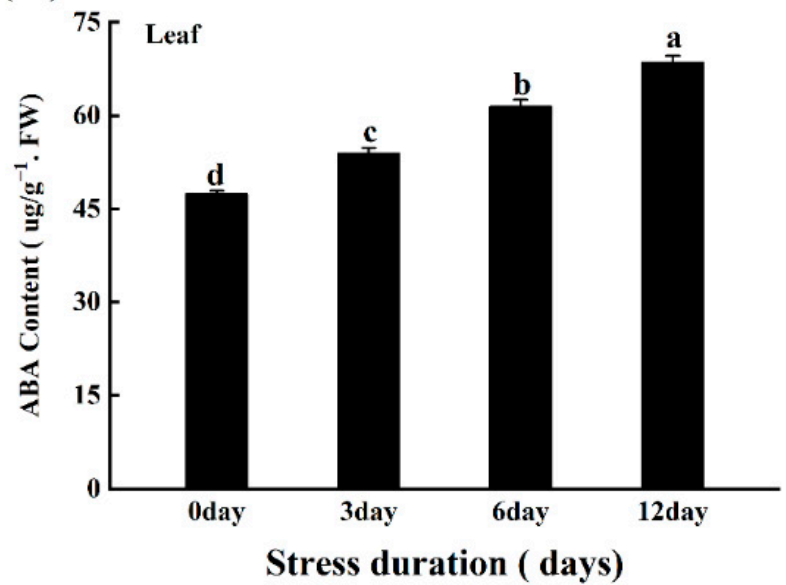

(B)

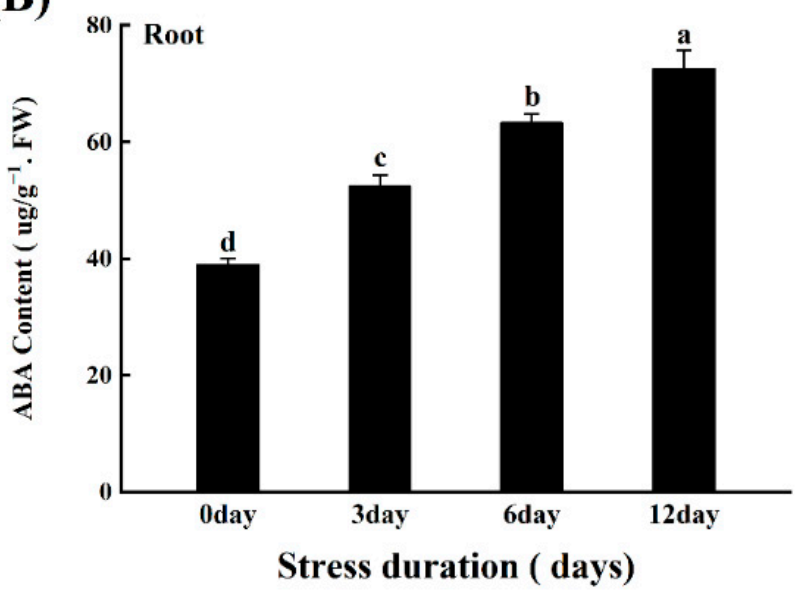

Figure 10. Effects of salt stress on Abscisic Acid in leaves (A) and roots (B) of tomato seedlings. Data was recorded after 12 days of growing tomato seedlings under control and salt stress for 12 days. Values are mean $\pm \mathrm{SD}$ (Standard Deviation) of three replications. Different letters indicate significant differences at $p \leq 0.05$ (Tukey's HSD test). 


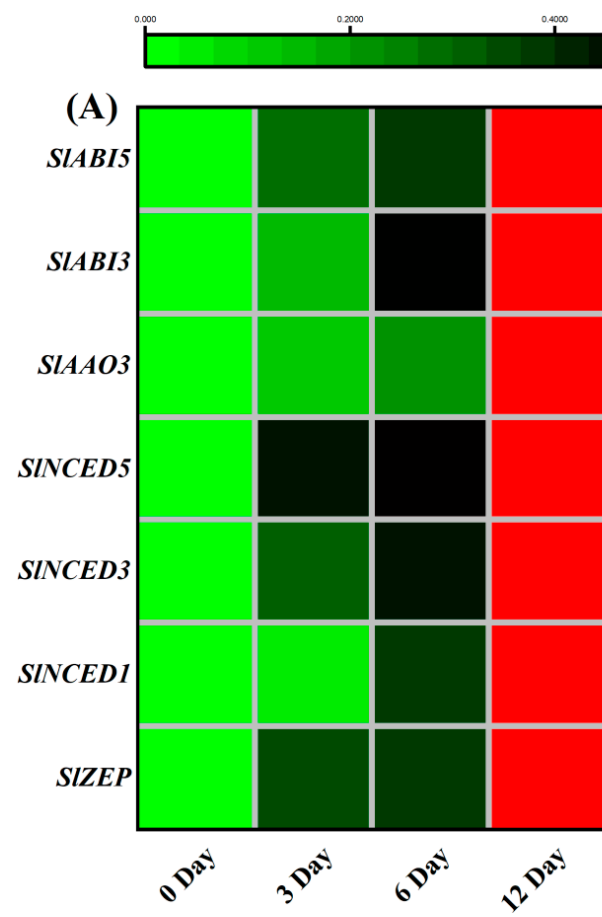

Stress duration (day)

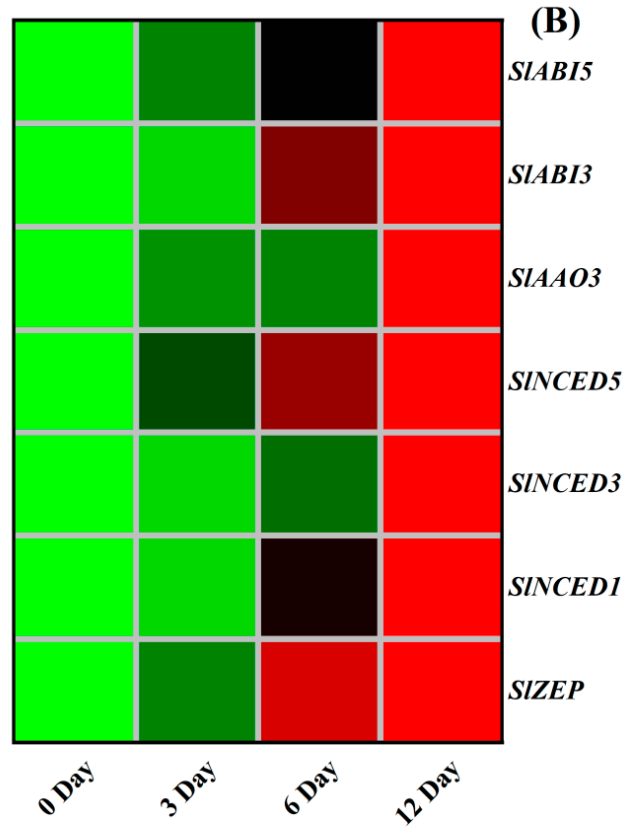

Stress duration (day)

Figure 11. Heatmap of selected genes related to ABA biosynthesis pathway quantified from tomato (A) Leaves; (B) roots after 12 days of salt treatment. The scale $\left(\log ^{2}\right.$ of the mean values after normalization; $n=3$ ) shows the increase in relative concentrations from green to red color, compared to control $(0 \mathrm{~h})$.

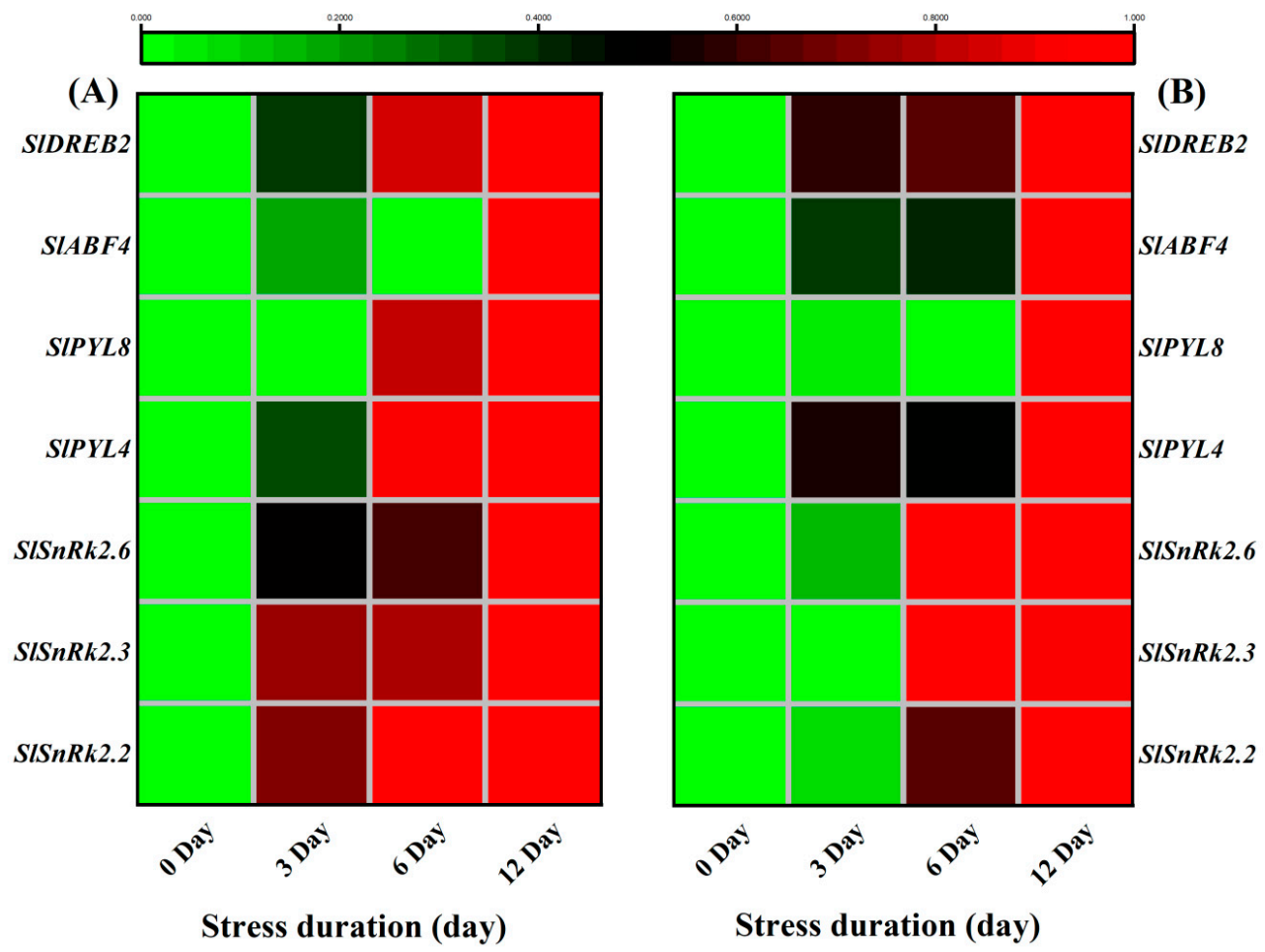

Figure 12. Heatmap of selected genes related to ABA signalling pathway. The relative expression level was quantified from tomato (A) Leaves and (B) roots after 12 days of salt treatment. The scale $\left(\log ^{2}\right.$ of the mean values after normalization; $\left.n=3\right)$ shows the increase in relative concentrations from green to red color, compared to control $(0 \mathrm{~h})$. 


\section{Discussion}

Soil salinity is an increasingly severe global problem, as salt hampers plant growth and development and reduces crop yield. In addition to naturally occurring soil salinity, salinization increases due to irrigation practices and climate change [27]. Therefore, in the present study, we explored the response of the tomato seedlings to three different durations of salt stress. Despite the salt-induced oxidative damage, we found that tomato seedlings adopted several strategies, including antioxidative scavenging of ROS and activation of stress-responsive gene signalling to detoxify oxidative stress.

One of the most common symptoms of plants under a stressful environment, e.g., salt or drought stress, includes leaf yellowing and growth inhibition, as plants serve their energy on survival rather than growth improvement [28]. Similarly, in the present study, increasing salt stress duration induced significant loss of photosynthetic pigments and markedly affected the morphological indices of the tomato seedlings (Figure 1). Such losses in pigment appear to be caused by the reduced activity of chlorophyll biosynthesis enzymes and increased chlorophyllase activity that degraded the chlorophyll content under salt stress $[29,30]$. In addition, sodium ions could disrupt the uptake of some important cation, i.e., $\mathrm{Mg}^{+2}$ that is the main part of the chlorophyll molecule, thus impacting the chlorophyll content of the leaves. Consequently, it impaired the growth and biomass accumulation in the roots and leaves of tomato seedlings. Consistent with our results, number of previous studies found the loss of pigment and growth inhibition of plants under salt stress [7,31,32].

The excess accumulation of sodium ions under the salt stress imposes osmotic stress, disrupting the water permeability and causing a disturbance in the water potential and turgidity of the cells [33]. Consistently, in the present study we also noticed that the values of $\Psi \mathrm{w}$ and $\Psi$ s become more negative, enhancing the corresponding $\Psi \mathrm{p}$ and osmotic adjustments. Ultimately, the RWC declined significantly (Figure 2). Such reduction in RWC of the cells are the primary indicator of the water stress that limits the water flow to the new cell elongation sites [13]. Similar results were reported earlier in peach [34] and tomato [35].

Moreover, salt stress-induced reduction in the water status of the cell results in stomatal closure, inhibiting the gaseous exchange and photosynthetic ability of the leaves [36]. Combined with the decreased pigment content, it ultimately impairs the photochemical efficiency of the plants. We consistently observed decreased values of the gas exchange parameter and maximal photochemical efficiency $(\mathrm{Fv} / \mathrm{Fm})$ in tomato seedlings (Supplementary Table S1), indicating the severe consequences of salt-induced osmotic stress on tomato seedling photosynthetic efficiency [36,37]. However, the marked increase in osmotic adjustments in tomato seedlings under salt stress also elucidates that it strives to counter the salinity-imposed osmotic stress by modifying the plant-water relations.

Osmotic regulation is a crucial self-defence mechanism produced by plants under stress. Plants produce high levels of osmoprotectants (e.g., soluble sugars, soluble proteins and proline content) to maintain the osmotic pressure and reduce cell water loss [38]. Proline and soluble sugars accumulated in response to stressful conditions act as a low molecular weight antioxidant that detoxifies the stress-induced toxicity and contributes to cellular osmotic adjustments [39]. In previous studies with various abiotic stresses, including salinity, these osmolytes increased significantly in chickpea [40], Amaranthus tricolor varieties [41], grapes [13] and tomatoes [42]. In addition, burst production of ROS under salt stress could destabilize the protein metabolism, decreasing the contents of soluble proteins in the plants [43]. Consistent with these reports, in our study, protein content decreased. At the same time, proline and soluble sugars were increased with increasing salt stress duration, suggesting that tomato plants suffered salt-induced toxicity and regulated their osmolytes to survive the water limitations under salt stress (Figure 3).

The declined growth parameters and disturbed plant-water relations due to salinity stress indicate a need to study the plant cells' sodium accumulation and minerals contents.

In the present study, the salt stress obviously enhanced the $\mathrm{Na}^{+}$accumulation in the roots and leaves of tomato seedlings, disturbing the $\mathrm{Na}^{+} / \mathrm{K}^{+}$ratio and ion homeostasis [44,45]. It could be due to the activation of the guard cells' outward rectifying K-channels (GORK), 
which enhanced the $\mathrm{Na}^{+}$ion accumulation by the outflow of $\mathrm{K}^{+}$and resulted in declined $\mathrm{K}^{+}$levels [44]. Besides the osmotic stress, the higher sodium accumulation in cells could also alter the uptake of other minerals, causing an imbalance in the contents of macro and micronutrients of the plants [45-48]. Similarly, in the present study we noticed a significant decline in the contents of important minerals like $\mathrm{P}, \mathrm{Mg}, \mathrm{Mn}$ and $\mathrm{K}$, which is consistent with the decreased growth and chlorophyll contents of the tomato seedlings under salt stress.

In addition, the significant increase in the contents of heavy metals like $\mathrm{Cu}$ and $\mathrm{Zn}$ under the salt stress could be attributed to the loss of ion specificity due to excessive salt accumulation in the roots and leaves of tomato seedlings [49]. Previous studies have reported the increase in $\mathrm{Ca}^{2+}$ ions as a response to salt stress to regulate plant response against salt stress [50]. In addition, the wheat genotypes with high salinity tolerance maintained the higher calcium content against salt stress, suggesting the important role of $\mathrm{Ca}$ ions in maintaining the ion homeostasis and enzyme activities under salt stress [49]. Consistently, our results also showed higher Ca content in tomato seedlings which could be a response to enduring the salt stress. Collectively, these results showed that salt stress negatively affected the macro and micronutrients in the tomato seedlings. Similar trends were noticed in previous studies with different plant species [51-54].

ROS production, MDA accumulation and electrolyte leakage are the basic biomarkers for oxidative stress under abiotic stresses [55,56]. In the present study, salt stress induced the production of excessive $\mathrm{O}_{2}{ }^{\bullet-}$ and $\mathrm{H}_{2} \mathrm{O}_{2}$. Consequently, the higher oxidative stress caused lipid peroxidation and MDA accumulation leading to cell membrane damage and increased leakage of electrolytes as compared to control plants. These results are similar to those in tomato [36], grape [13], and chickpea [40] and demonstrate the severe consequences of salt stress on the growth and development of plants (Figure 4).

Plants have developed different tools against stress which could regulate redox homeostasis and protect plant cells from oxidative damage by scavenging excessive ROS [57]. For instance, SOD is one of the most important antioxidant enzymes that carry out the dismutation of superoxide anion $\left(\mathrm{O}_{2}{ }^{\bullet-}\right)$ into oxygen $\left(\mathrm{O}_{2}\right)$ and comparatively less toxic ROS, i.e., hydrogen peroxide $\left(\mathrm{H}_{2} \mathrm{O}_{2}\right)$. Subsequently, the other major antioxidant enzymes like POD, APX and CAT detoxify the $\mathrm{H}_{2} \mathrm{O}_{2}$ to water [58-60]. In the present study, salt stressinduced activities of various enzymatic (SOD, POD, CAT, APX, GR) and non-enzymatic antioxidants (AsA, GSH) in the tomato seedlings. These results are in line with the previous reports in tomato [30] and other species like Solanum Lycopersicum [36], O. sativa [61], C. arietinum [30], B. juncea $[62,63]$ and wheat [64]. It suggested that tomato seedlings retained the capacity to tolerate or detoxify the salt-induced toxicity for their survival. Another important antioxidants-mediated protective mechanism in plants includes AsA-GSH cycle that assists the antioxidant enzymes to scavenge the excessive ROS. Both AsA and GSH are potent antioxidants and are considered the buffering agents in redox reactions to protect the plasma membrane from stress-induced oxidation [65]. In this perspective, the $\mathrm{H}_{2} \mathrm{O}_{2}$ produced after superoxide dismutation is detoxified by APX into $\mathrm{H}_{2} \mathrm{O}$ using AsA as the substrate. In the present study, the increased GR activity after salt stress provides GSH, reducing DHAR to dehydroascorbate (DHA) and then to AsA via the AsA-GSH cycle. Similarly, GSH is oxidized to GSSG and subsequently recycled by GR. Thus, the ratio of GSH/GSSG is essential for sustaining the cell redox state [66]. The increase in the activities of SOD, POD, CAT, APX, GR, MDHAR, DHAR, and AsA, DHA was observed in the current study. The ratio of AsA/DHA, GSH, GSSG, and the ratio of GSH/GSSG and proline content in tomato seedlings was observed to be affected by salinity (Figures 5-7), implying that tomato seedlings attempted to maintain redox regulation under salt stress. It was also confirmed at the transcriptomic level, as the relative transcript levels of antioxidant enzymes showed a similar trend with increasing salt stress duration. A similar gene expression pattern was previously observed in tomato under high temperature stress $[67,68]$.

In addition, salinity stress also caused a significant increase in polyamines metabolism as suggested by the increase in the activities of three key enzymes named DAO, PAO and ADC (Figure 8). Similarly, in previous reports, salinity stress enhanced the ADC and 
ODC activities in tomato roots, indicating that both enzymes are responsible for stress tolerance [69]. Furthermore, salinity stress also induced a slight increase in PAO activity [70]. It has been well known that polyamines play important role under stress conditions by modulating ROS homeostasis and regulating the antioxidative mechanism to suppress the ROS production under stress conditions [71]. Therefore, in the present study, the significant increase in enzymes involved in polyamines synthesis could be linked with the signaling regulation to enhance the responsiveness of tomato seedlings against salt stress (Figure 8).

The plasma membrane-localized respiratory burst oxidase homolog $(\mathrm{RBOH})$ proteins generate reactive oxygen species (ROS). AtrbohD and AtrbohF, the major NADPH oxidases responsible for ABA-induced ROS production in Arabidopsis, are involved in stomatal closure [72]. OST1 interacts with AtrbohD and AtrbohF and phosphorylates Ser174 in AtrbohF [73]. To acquire further molecular insights into the salt tolerance mechanism of WT Ailsa Craig, we tested the expression of several TFs, ABA biosynthesis enzymes and signalling and defence-related proteins in WT seedlings. We noticed a significant upregulation of all the studied RBOH genes with the increasing salt stress duration (Figure 9). Combined with the accumulation of hydrogen superoxide radicals, it could be suggested that salt-induced over-production of $\mathrm{H}_{2} \mathrm{O}_{2}$ activated the $\mathrm{RBOH}$ signalling mechanism, which regulated the various adaptive mechanisms to counter the salt-induced osmotic stress in tomato seedlings. In previous studies with different abiotic stresses, including low temperature [74], cold [74] and salinity [75], the acclimation to the stresses was found associated with the increased transcript levels of $R B O H 1$ [76]. Furthermore, in Arabidopsis, the expressions of $A$ trbohD and AtrbohF were upregulated and $\mathrm{Na}^{+} / \mathrm{K}^{+}$homeostasis in wild-type Arabidopsis seedlings that grow on MS medium containing $\mathrm{NaCl}$ [77]. Previous studies with sugar beet revealed that BvRBOHE, BvRBOHF, and BvRBOHH downregulates under salt stress. However, we found significant upregulation of both $S I R B O H-E, S I R B O H-$ $F$ after 12 days of salt stress and only SIRBOH-H was found downregulated in roots after 12 days of salt stress (Figure 9). It suggests the significant role of $\mathrm{RBOH}$ transcription factors in tomato salt-stress acclimatization. Consistent with our results, a genome-wide identification of $\mathrm{RBOH}$ genes showed significant upregulation $\mathrm{RBOHA}, \mathrm{RBOHD}, \mathrm{RBOHF}$ and $R B O H G$ under drought stress. Altogether, the significant upregulation of $\mathrm{RBOH}$ genes, particularly after 12 days of salt stress, strongly suggests their role in regulating the response of tomato seedlings to long-term salinity stress.

The phytohormone ABA plays a crucial role in regulating a range of plant physiological processes in response to various stresses [78]. ABA functions as an essential secondary signalling molecule to activate a kinase cascade and mediate gene expression during salt stress [79]. Osmotic stress, such as drought and high salinity, dramatically increases the ABA level, which induces the expression of many genes involved in stress responses [80]. In the present study, we consistently observed the ABA accumulation with the increasing duration of the salt stress (Figure 10), suggesting that tomato seedlings regulated the ABA levels and the expression of relevant genes for survival against the salt-induced damages. Previously, biochemical and genetic studies have shown that 9-cis-epoxycarotenoid dioxygenase (NCED) is a key rate-limiting enzyme in ABA biosynthesis and its overexpression in tomato and other plants causes abscisic acid (ABA) accumulation, affecting the stress responsiveness of plants [81-83]. Similarly, zeaxanthin epoxidase (ZEP) and aldehyde oxidase $(A A O 3)$ are also critical regulatory genes in the ABA biosynthesis pathway in Arabidopsis and other plant species [84]. Therefore, significant accumulation of ABA in roots and leaves of tomato seedlings suggests that salt stress induced the expression of ABA biosynthesis genes (ZEP, ABI3, ABI5, NCED1 and NCED2) that upregulated the corresponding ABA abundance levels to regulate the plant growth and homeostasis under salt stress. Previously, AtZEP-overexpressing plants exhibiting vigorous growth, enhanced de novo ABA biosynthesis, increased the expression level of salt stress-related genes, and suggested the critical role of ABA biosynthesis and ABA signalling against salt stress [85]. Altogether, it shows that enhanced biosynthesis of ABA is a key regulatory strategy of tomato seedlings to survive under salt stress (Figure 11). 
In addition to ABA-biosynthesis induction, salt stress also activated the downstream ABA signalling mechanism that controls ABA-regulated gene expression to enhance stress tolerance [86]. Various gene families like SnRks [87], DREBs [88,89], PYLs [90] and ABFs [91] are involved in ABA signalling that improves the tolerance of plants under stressful environments [92]. Among SnRKs, Subfamily 2 of SNF1-related protein kinase (SnRK2) is considered as a positive global regulator of abscisic acid signalling [87]. Previously, it was noticed that $S n R K 2.2, S n R K 2.6$ and $S n R K 2.3$ activated the $A R E B 1 / A B F 2, A R E B 2 / A B F 4$, and $A B F 3$ as a response to osmotic stress at the vegetative stage [93]. Therefore, the significant upregulation of the ABF4, PYL4 and PYL8 in the present study could also be linked to the higher expression of SnrK genes to improve the ABA-regulated signalling against the salt stress. Consistently, a recent study showed the alterations in transcriptional levels of several salt stress-responsive genes like SIPP2C37, SIPYL4, SIPYL8, SINAC022, SINAC042, and SISnRK2 family by $P p S n R K 1 \alpha$, signifying that $S n R K 1 \alpha$ is involved in the ABA signalling pathway to improve tomato salt tolerance [94]. Functional analysis of the AREB/ABFs revealed that these proteins were positive regulators of the ABAdependent signalling pathways under drought conditions [95]. Similarly, physiological, biochemical and transcriptomic analyses showed that SIDREB2 enhanced plant tolerance to salinity by improvement of $\mathrm{K}^{+} / \mathrm{Na}^{+}$ratio and proline and polyamines biosynthesis [96]. Altogether, these reports suggested that the upregulation of ABA-signalling related genes in tomato seedlings regulated various downstream mechanisms involving the accumulation of osmolytes, osmotic adjustments and maintaining a turgor potential that could help the plant to survive under the 12 days long salt tress (Figure 12). Our results are consistent with the previous reports regarding the ABA-accumulation and signalling under the osmotic or salt stress $[97,98]$.

\section{Materials and Methods}

\subsection{Plant Material and Salt Stress Application}

The tomato (Lycopersicon esculentum Mill.) the salt-sensitive cultivar, "Ailsa Craig" [99] was used in the present study. Seeds were collected from the Laboratory of Protected Horticulture, College of Horticulture, Nanjing Agricultural University, Nanjing, China and surfaced sterilized with $10 \%$ Sodium hypochlorite solution $(\mathrm{NaClO})$, rinsed five times with deionized dd $\mathrm{H}_{2} \mathrm{O}$ (double distilled water) and incubated at $28{ }^{\circ} \mathrm{C}$ in Petri dishes under dark conditions until the emergence of the radicle. The seedlings were grown in half-strength Hoagland's solution under controlled conditions $\left(25^{\circ} \mathrm{C} / 18^{\circ} \mathrm{C}\right.$, day/night temperature, 16-h light/8-h dark cycle and 40-50\% relative humidity). Subsequently, at the four-leaf stage, tomato seedlings were subjected to high salinity stress treatment $(120 \mathrm{mM} \mathrm{NaCl}$ solution) for 3, 6 and 12 days [100] while the control plants were grown under half-strength Hoagland's solution without salt stress during this duration. Each treatment contained three biological repeats. At each sampling point, samples were collected in liquid nitrogen and stored at $-80^{\circ} \mathrm{C}$ for further physiological, biochemical and molecular analysis.

\subsection{Determination of Seedling Index and Pigment Contents}

Different morphological parameters like plant height and fresh and dry weight of plant parts (root, shoot, and leaves) were recorded using meter scale and electronic balance, respectively. After recording the fresh weight, the samples were dried in a hot air oven at $80{ }^{\circ} \mathrm{C}$ for $72 \mathrm{~h}$ to measure the dry weight. Subsequently, the seedling index (SI) was calculated as follows [75,101,102]:

$$
\mathrm{SI}=\left(\frac{\text { Stem diameter }}{\text { Plant height }}+\frac{\text { Root dry weight }}{\text { Shoot dry weight }}\right) \times \text { tomato seedling dry weight }
$$

The chlorophylls and carotenoid pigments were extracted by grinding $0.5 \mathrm{~g}$ of fresh leaf sample with $80 \%$ acetone. Subsequently, the absorbance of the extract at $663.3 \mathrm{~nm}$, $646.6 \mathrm{~nm}, 510 \mathrm{~nm}$ and $470 \mathrm{~nm}$ was analyzed by a UV-1800 spectrophotometer and pigment contents was calculated according to $[103,104]$ 


\subsection{Measurement of Plant-Water Relations}

The plant-water relations were measured by calculating the relative water content (RWC), leaf water potential $(\Psi \mathrm{t})$, osmotic potential $(\Psi \pi)$, Turgor potential and Osmotic adjustment of the youngest completely expanded leaf. Measurements were performed at 3-h intervals from 9:00 a.m. to 6:00 p.m. Leaf water potentials ( $\Psi \mathrm{t}$ ) were measured using a dew-point psychrometer (WP4, Decagon Devices, Washington) three times at 8:00 a.m., 1:00 p.m. and 5:00 p.m. The osmotic potential $(\Psi \pi)$ was measured on frozen/thawed leaf samples and the pressure potential ( $\Psi \mathrm{p})$ was estimated as the difference between $\Psi \mathrm{t}$ and $\Psi \pi$, assuming a matric potential equal to 0 . Leaf osmotic adjustment (OA) was determined as the difference $\Psi \pi_{0} \mathrm{~V} 0-\Psi \pi \mathrm{V}$, where $\Psi \pi_{0} \mathrm{~V} 0$ is the product of [osmotic potential] $\times$ [osmotic volume] of unstressed plants and $\Psi \pi \mathrm{V}$ is the product of [osmotic potential] $\times$ [osmotic volume] of leaves from salinized plants. For each measurement, the osmotic volume was approximated by the corresponding relative water content value (RWC) calculated as [102]:

$$
\text { RWC }=\left(\frac{\text { Fresh weight }- \text { Dry weight }}{\text { Saturated weighr }- \text { Dry weight }}\right) \times 100
$$

\subsection{Determination of Protein, Sugars and Proline Content}

For protein extraction, $0.3 \mathrm{~g}$ fresh weight of samples were homogenized in a pre-chilled mortar with $600 \mathrm{uL}$ of protein extraction buffer $(50 \mathrm{mM}$ Tris- $\mathrm{HCl}(\mathrm{pH} \mathrm{8.0)}), 150 \mathrm{mM} \mathrm{NaCl}$, $1 \mathrm{mM}$ EDTA, 1\% (v/v) NP-40, 1\% (w/v) sodium deoxycholate, $0.1 \%$ sodium dodecyl sulfate $(w / v)$ and $1 \mathrm{mM}$ PMSF). The extracted protein was quantified according to the Bradford kit (FD2003 by FDbio Science Biotech Co., Ltd., Hangzhou, China) [105].

Soluble sugar content was determined by using a specified sugar assay kit (145-1-1) and BCA assay kit (BCAP-1-W) by Nanjing Jiancheng Bioengineering Institute, Nanjing, China and Suzhou Comin Biotechnology Co., Ltd., Anhui, China, respectively as per their instructions [106].

For proline content, the fresh leaves sample was homogenized in 3\% sulfosalicylic acid and the reaction mixture containing the extract, ninhydrin, glacial acetic acid (1:1:1) was incubated at $90^{\circ} \mathrm{C}$ for $1 \mathrm{~h}$. Subsequently, the toluene was added when the solution got cool, and absorbance was measured at $520 \mathrm{~nm}$ using a BioMate spectrophotometer [107].

\subsection{Determination of Nutrient Elements Content in Leaves and Roots}

Dried roots and leaves of tomato seedlings were oven-dried at $80{ }^{\circ} \mathrm{C}$ and ground using a mortar and pestle; $0.1 \mathrm{~g}$ of powder was then digested with $5 \mathrm{ml}$ of nitric acid for $3 \mathrm{~h}$, and then nutrient elements concentrations were analyzed using an atomic absorption spectrophotometer (Varian spectra AA 220, Varian, Palo Alto, CA, USA), according to the method described by [108]

\subsection{Quantification of Reactive Oxygen Species (ROS), Oxidative Damage and Root Activity}

The oxidative stress was estimated by quantifying the amount of $\mathrm{O}_{2}{ }^{\bullet-}$ and $\mathrm{H}_{2} \mathrm{O}_{2}$ as described in the previously published protocols [109]. $\mathrm{O}_{2}{ }^{\bullet-}$ was measured by mixing the supernatant of the processed leaf sample with phosphate buffer (50 mM; pH 7.8) and hydroxylamine hydrochloride $(10 \mathrm{mM})$. The absorbance was checked at 530 after the incubation of reaction mixture incubation for about a half-hour at room temperature. For $\mathrm{O}_{2}{ }^{\bullet-}$, the leaf sample processed in TCA $(0.1 \%)$ and centrifuged $\left(12,000 \times g ; 15 \mathrm{~min} ; 4^{\circ} \mathrm{C}\right)$. The obtained supernatant was mixed with KI (1 M) and phosphate buffer (0.1 M; pH 7.8) and absorbance was noted at $390 \mathrm{~nm}$ after the dark incubation for one hour.

We quantified the malonaldehyde (MDA) content to check the lipid peroxidation using the method of [109] to estimate the oxidative damage caused by salinity stress. In brief, $0.3 \mathrm{~g}$ fresh leaf sample was homogenized in \% TCA (Trichloroacetic acid), centrifuged at $10,000 \times g$ for $5 \mathrm{~min}, 1 \mathrm{~mL}$ supernatant was mixed with \% TBA (Thiobarbitu-ric acid), 
30 min boiling, and the absorption was measured. In addition, the cell membrane integrity was estimated by calculating the membrane stability index (MSI) as described by [37,110].

The root activity was estimated following the TTC method as described by [111], and root activity was expressed as the capacity of root deoxidization $\left(\mathrm{mg} \mathrm{g}^{-1} \mathrm{~h}^{-1}\right)$.

\subsection{Determination of Photosynthetic Rate, Chlorophyll Fluorescence}

After salt stress for $12 \mathrm{~d}$, the photosynthetic rate was measured with the portable photosynthesis system (LI-6400; Li-COR, Lincoln, NE, USA), maintaining the $\mathrm{CO}_{2}$ concentration at $380 \mu \mathrm{mol} \mathrm{mol}^{-1}$ and photosynthetic photon flux density at $1000 \mu \mathrm{mol} \mathrm{m}^{-2} \mathrm{~s}^{-1}$.

Tomato plants were dark-adapted for 30 min to measure the Fv/Fm with the Portable fluorometer (PAM-2100, Walz, Effeltrich, Germany) as previously described [112].

\subsection{Assay of Enzymatic and Non-Enzymatic Antioxidants Activity}

For the assay of antioxidant enzymes, the $0.2 \mathrm{~g}$ fresh leaf tissues were homogenized in phosphate buffer (50 mM, pH 7.8) in a pre-chilled mortar, followed by a centrifugation $\left(12,000 \times g\right.$ at $\left.4{ }^{\circ} \mathrm{C}\right)$ for $20 \mathrm{~min}$. The samples were stored at $-80{ }^{\circ} \mathrm{C}$ for further analysis. SOD activity was checked by using nitro blue tetrazolium (NBT) [113]. 50\% inhibition of photoreduction of NBT by enzyme activity was considered as one unit of SOD activity. POD activity was measured by the oxidation of guaiacol in a reaction mixture containing phosphate buffer $(0.2 \mathrm{M}, \mathrm{pH} 6.0)$, guaiacol $(50 \mathrm{mM})$ and hydrogen peroxide $(2 \%)$ and absorbance was checked at $470 \mathrm{~nm}$. CAT was measured according to the previously described protocols by the reduction of $\mathrm{H}_{2} \mathrm{O}_{2}$ as the decrease in absorbance decreased at $240 \mathrm{~nm}[114,115]$. APX activity was induced in a mixture of phosphate buffer (50 $\mathrm{mM}$, $\mathrm{pH} 7.0$ ), $0.1 \mathrm{mM}$ EDTA, $0.1 \mathrm{mM} \mathrm{H}_{2} \mathrm{O}_{2}$ and $0.5 \mathrm{mM}$ ascorbate by adding the fraction of enzyme extract [116]. The change in absorbance was recorded at $290 \mathrm{~nm}$. GR activity was measured using the specific kit by Solarbio Life Science, Beijing, China, according to the manufacturer's instruction. The MDHAR (Monodehydro ascorbate reductase) and DHAR (dehydro ascorbate reductase) activities were estimated according to the previously described protocols at $340 \mathrm{~nm}$ and $265 \mathrm{~nm}$, respectively [116,117].

For non-enzymatic antioxidants, i.e., ascorbate (AsA-DHA) and Glutathione (GSHGSSG), the samples were prepared by homogenizing $0.2 \mathrm{~g}$ of leaf sample in $6 \%$ pre-chilled $\mathrm{HClO}_{4}$. The supernatant obtained after centrifugation $\left(12,000 \times g ; 15 \mathrm{~min} ; 4^{\circ} \mathrm{C}\right)$ of homogenized sample was stored at $-80^{\circ} \mathrm{C}$ for further analysis. Later on, the contents of AsA-DHA, and GSH-GSSG were obtained by following the previously described protocols [118-120].

\subsection{Determination of Activities of Ornithine Decarboxylase (ODC), Arginine Decarboxylase} $(A D C)$ and Polyamine Oxidase (PA)

A total of $500 \mathrm{mg}$ fresh plant tissue was homogenized in potassium phosphate buffer (100 mM, pH 8.0) containing PMSF (0.1 mM), pyridoxal phosphate (1 mM PLP), dithiothreitol (5 mM, DTT), 1mM EDTA, 10mM ascorbic acid and $0.1 \%$ PVP. After centrifugation at $12,000 \times \mathrm{g}$ for $40 \mathrm{~min}$ at $4{ }^{\circ} \mathrm{C}$ supernatants were dialyzed and used for assaying the enzyme activity. Activities of ADC or ODC were determined according to [5] in an assay mixture containing tris-buffer (100 mM, pH 7.5), EDTA, pyridoxal phosphate (50 mM), DTT and $300 \mu \mathrm{L}$ enzyme extract. After incubation at $37^{\circ} \mathrm{C}$ for $2 \mathrm{~min}, 200 \mu \mathrm{L}$ of L-arginine (for ADC) or $200 \mu \mathrm{L}$ of L-ornithine (for ODC) were added and mixtures were again incubated for $1 \mathrm{~h}$ at $37^{\circ} \mathrm{C}$. After that, $5 \%$ perchloric acid was added and centrifuged again at $3000 \times g$ for $10 \mathrm{~min}$. To $500 \mu \mathrm{L}$ supernatant were added $2 \mathrm{mM} \mathrm{NaOH}$ and benzoyl chloride, and the mixture was thoroughly mixed and incubated at $37{ }^{\circ} \mathrm{C}$ for $30 \mathrm{~min}$. $\mathrm{NaCl}(2 \mathrm{~mL})$ and ether $(3 \mathrm{~mL})$ were added the mixture was centrifuged again at $1500 \times g$ for $5 \mathrm{~min}$. After extraction with ether, evaporated ether phase was redissolved in methanol $(60 \%)$ and read at $254 \mathrm{~nm}$.

To determine PAO activity fresh leaf tissue was homogenized in $100 \mathrm{mM}$ phosphate buffer ( $\mathrm{pH}$ 6.5) and the homogenate was centrifuged for $20 \mathrm{~min}$ at $10,000 \times g$ at $4{ }^{\circ} \mathrm{C}$. Reaction mixture contained $100 \mathrm{mM}$ phosphate buffer (pH 6.5), $200 \mu \mathrm{L} 4$-aminoantipyrine/N, 
$\mathrm{N}$-dimethylaniline solution, $100 \mu \mathrm{L}$ horseradish peroxidase and $200 \mu \mathrm{L}$ enzymes extract. Change in optical density was monitored at $254 \mathrm{~nm}$ after initiating reaction by adding $20 \mathrm{mM}$ of each spermidine and spermine [121].

\subsection{Determination of $A B A$ Content}

ABA was measured in seedlings after $48 \mathrm{~h}$ of exposure to salt-stress tomato plants. Plant tissue ( $0.2 \mathrm{~g} \mathrm{FW})$ was homogenized with $5 \mathrm{~mL}$ extraction buffer $(80 \%$ acetone, $100 \mathrm{mg}^{-1}$ butylated hydroxytoluene, $0.5 \mathrm{~g}^{-1}$ citric acid) and centrifuged for $5 \mathrm{~min}$ at $12,000 \times \mathrm{g}$. The supernatant was collected, dried and resuspended in $0.5 \mathrm{~mL}$ of TBS buffer $\left(6.05 \mathrm{~g}^{-1}\right.$ Tris, $0.20 \mathrm{mg}^{-1} \mathrm{MgCl}_{2}$ and $\left.8.8 \mathrm{~g} / 1 \mathrm{NaCl}, \mathrm{pH} 7.8\right)$. ABA was quantified using an indirect ELISA [122]. ABA-BSA conjugates were prepared according to [123] as described [124]. ABA levels are expressed in $\mathrm{ng}(\mathrm{g} \mathrm{FW})^{-1}$.

\subsection{Quantitative Real-Time PCR ( $q R T-P C R)$}

According to the manufacturer's instructions, total RNA was extracted from tomato leaves and roots using the RNAsimple Total RNA Kit (Tiangen, DP419). The HiScript II Q RT SuperMix for qPCR (+gDNA wiper) Kit was used to reverse-transcribe total RNA (1 g) to cDNA (Vazyme, R223-01). The ChamQ SYBR qPCR Master Mix (Vazyme, Q311-02) was used in the StepOnePlusTM Real-Time PCR Method to conduct the quantitative real-time PCR (qPCR) assays (Applied Biosystems, United States of America). The PCR conditions consisted of denaturation at $95^{\circ} \mathrm{C}$ for $3 \mathrm{~min}$, followed by 40 cycles of denaturation at $95^{\circ} \mathrm{C}$ for $10 \mathrm{~s}$, annealing at $58{ }^{\circ} \mathrm{C}$ for $10 \mathrm{~s}$, and extension at $72{ }^{\circ} \mathrm{C}$ for $20 \mathrm{~s}$. The tomato actin gene was used as an internal control. Gene-specific primers were designed according to cDNA sequences, as described in Table S2. Relative gene expression was calculated as described by [125].

\subsection{Statistical Analysis}

The data presented in the study was analyzed by the SPSS 20.0 (SPSS Inc., Chicago, IL, USA). The data is presented in the form of mean \pm standard deviation according to Tukey's test. The graphs and heat maps have been created using the Origin Pro 2021. At least three independent repeats were performed for each measurement. All the software used in the data analysis were provided by Nanjing Agricultural University, Nanjing, Jiangsu, China.

\section{Conclusions}

Salinity is one of the important constraints that adversely affect the productivity of the tomato plants. Therefore, in the present study, we evaluated the comprehensive response of tomato towards progressive salt stress treatments at physiological and molecular levels. It was noticed that salt stress significantly reduced the water content, growth and development of tomato plants and inhibited the photosynthesis. In addition, the oxidative damage and ROS accumulation increased concurrently with increasing salt stress duration. However, with increasing salt stress duration, we noticed some interesting stress response of tomato plants involving the accumulation of osmoprotectants like proline and soluble sugars, and upregulation of major enzymatic and non-enzymatic antioxidants to maintain the turgor potential and detoxify the excessive ROS production under 12 days long salt stress.

At the same time, ROS production and water limitation under salt stress also activated the various molecular factors including RBOH TFs, and ABA biosynthesis and signaling genes, respectively. These genes are well-known molecular players under stressful environment that regulate the ion hemostasis, osmotic adjustments and osmolytes (soluble sugars and proline) to protect plants from stress-induced damage. Therefore, in the present study, the combination of these stress responses employed by tomato plants could help to survive the salt stress. These results might provide the basis for the development of salt-tolerant tomato varieties for better production under the salt stress conditions. In addition, a comparative physio-molecular study of salt stress responses at seedling and 
reproductive stage could be a good subject for future studies to understand the survival capacity of tomato plants at different growth stages.

Supplementary Materials: The following are available online at https:/ / www.mdpi.com/article/10 $.3390 / \mathrm{ijms} 23031603 / \mathrm{s} 1$.

Author Contributions: Conceptualization, A.R. and S.G.; methodology, A.R., S.G. and A.M.U.D.; software, A.R. and A.M.U.D.; validation, S.G., J.S. and S.S.; formal analysis, A.R.; investigation, A.R.; resources, S.G.; data curation, A.R. and Y.W.; writing-original draft preparation, A.R. and A.M.U.D.; writing-review and editing, Y.W., A.M.U.D., J.S. and S.S.; visualization, A.R., Y.W.; supervision, Y.W. and S.G.; project administration, J.S. and S.G.; funding acquisition, S.G. All authors have read and agreed to the published version of the manuscript.

Funding: This work financially supported the China Agriculture Research System (CARS-23-B16). The supporters did not play any role in the design, collection, analysis, interpretation of the relevant data, or in writing the manuscript.

Institutional Review Board Statement: Not applicable.

Informed Consent Statement: Not applicable.

Data Availability Statement: Excluded (because all the data and Supplementary Materials have already been provided in the paper).

Acknowledgments: All the authors are thankful to Fidelis Azi (azifideel@yahoo.com), Anthony Pius Bassey (bassey_ap44@outlook.com) and Allan Samo (allansamo@njau.edu.cn) for their sincere collaborating efforts in language improvement of this manuscript. All the authors are thankful to Abdul Jalal for his sincere suggestions for the improvement of this manuscript.

Conflicts of Interest: The authors declare no conflict of interest.

\section{References}

1. Tester, M.; Davenport, R. Na+ Tolerance and $\mathrm{Na}^{+}$Transport in Higher Plants. Ann. Bot. 2003, 91, 503-527. [CrossRef] [PubMed]

2. Li, D.; Zhang, Y.; Hu, X.; Shen, X.; Ma, L.; Su, Z.; Wang, T.; Dong, J. Transcriptional Profiling of Medicago Truncatula under Salt Stress Identified a Novel CBF Transcription Factor MtCBF4 That Plays an Important Role in Abiotic Stress Responses. BMC Plant Biol. 2011, 11, 1-19. [CrossRef] [PubMed]

3. Türkan, I.; Demiral, T. Recent Developments in Understanding Salinity Tolerance. Environ. Exp. Bot. 2009, 67, 2-9. [CrossRef]

4. Ahanger, M.A.; Agarwal, R.M. Salinity Stress Induced Alterations in Antioxidant Metabolism and Nitrogen Assimilation in Wheat (Triticum aestivum L) as Influenced by Potassium Supplementation. Plant Physiol. Biochem. 2017, 115, 449-460. [CrossRef] [PubMed]

5. Ahanger, M.A.; Qin, C.; Maodong, Q.; Dong, X.X.; Ahmad, P.; Abd-Allah, E.F.; Zhang, L. Spermine Application Alleviates Salinity Induced Growth and Photosynthetic Inhibition in Solanum Lycopersicum by Modulating Osmolyte and Secondary Metabolite Accumulation and Differentially Regulating Antioxidant Metabolism. Plant Physiol. Biochem. 2019, 144, 1-13. [CrossRef] [PubMed]

6. Almeida, D.M.; Oliveira, M.M.; Saibo, N.J.M. Regulation of $\mathrm{Na}^{+}$and $\mathrm{K}^{+}$Homeostasis in Plants: Towards Improved Salt Stress Tolerance in Crop Plants. Genet. Mol. Biol. 2017, 40, 326-345. [CrossRef]

7. Munns, R.; Tester, M. Mechanisms of Salinity Tolerance. Annu. Rev. Plant Biol. 2008, 59, 651-681. [CrossRef]

8. Mittler, R.; Vanderauwera, S.; Gollery, M.; Van Breusegem, F. Reactive Oxygen Gene Network of Plants. Trends Plant Sci. 2004, 9 , 490-498. [CrossRef]

9. Zhu, J.-K. Plant Salt Tolerance. Trends Plant Sci. 2001, 6, 66-71. [CrossRef]

10. Calero Hurtado, A.; Chiconato, D.A.; de Prado, R.M.; da Sousa Junior, G.; Gratão, P.L.; Felisberto, G.; Olivera Viciedo, D.; dos Santos, D.M. Different Methods of Silicon Application Attenuate Salt Stress in Sorghum and Sunflower by Modifying the Antioxidative Defense Mechanism. Ecotoxicol. Environ. Saf. 2020, 203, 110964. [CrossRef]

11. Devkar, V.; Thirumalaikumar, V.P.; Xue, G.P.; Vallarino, J.G.; Turečková, V.; Strnad, M.; Fernie, A.R.; Hoefgen, R.; Mueller-Roeber, B.; Balazadeh, S. Multifaceted Regulatory Function of Tomato SITAF1 in the Response to Salinity Stress. New Phytol. 2020, 225, 1681-1698. [CrossRef] [PubMed]

12. Isah, T. Stress and Defense Responses in Plant Secondary Metabolites Production. Biol. Res. 2019, 52, 1-25. [CrossRef] [PubMed]

13. Haider, M.S.; Jogaiah, S.; Pervaiz, T.; Yanxue, Z.; Khan, N.; Fang, J. Physiological and Transcriptional Variations Inducing Complex Adaptive Mechanisms in Grapevine by Salt Stress. Environ. Exp. Bot. 2019, 162, 455-467. [CrossRef]

14. Sohrabi, S.; Ebadi, A.; Jalali, S.; Salami, S.A. Enhanced Values of Various Physiological Traits and VvNAC1 Gene Expression Showing Better Salinity Stress Tolerance in Some Grapevine Cultivars as Well as Rootstocks. Sci. Hortic. 2017, 225, 317-326. [CrossRef] 
15. Hasanuzzaman, M.; Bhuyan, M.H.M.B.; Zulfiqar, F.; Raza, A.; Mohsin, S.M.; Al Mahmud, J.; Fujita, M.; Fotopoulos, V. Reactive Oxygen Species and Antioxidant Defense in Plants under Abiotic Stress: Revisiting the Crucial Role of a Universal Defense Regulator. Antioxidants 2020, 9, 681. [CrossRef]

16. Liang, W.; Ma, X.; Wan, P.; Liu, L. Plant Salt-Tolerance Mechanism: A Review. Biochem. Biophys. Res. Commun. 2018, 495, $286-291$. [CrossRef]

17. Miller, G.; Suzuki, N.; Ciftci-Yilmaz, S.; Mittler, R. Reactive Oxygen Species Homeostasis and Signalling during Drought and Salinity Stresses. Plant Cell Environ. 2010, 33, 453-467. [CrossRef]

18. Kaur, G.; Sharma, A.; Guruprasad, K.; Pati, P.K. Versatile Roles of Plant NADPH Oxidases and Emerging Concepts. Biotechnol. Adv. 2014, 32, 551-563. [CrossRef]

19. Kurusu, T.; Kuchitsu, K.; Tada, Y. Plant Signaling Networks Involving Ca ${ }^{2+}$ and Rboh/Nox-Mediated ROS Production under Salinity Stress. Front. Plant Sci. 2015, 6, 1-8. [CrossRef]

20. Chapman, J.M.; Muhlemann, J.K.; Gayomba, S.R.; Muday, G.K. RBOH-Dependent ROS Synthesis and ROS Scavenging by Plant Specialized Metabolites to Modulate Plant Development and Stress Responses. Chem. Res. Toxicol. 2019, 32, 370-396. [CrossRef]

21. Li, X.; Li, Y.; Ahammed, G.J.; Zhang, X.N.; Ying, L.; Zhang, L.; Yan, P.; Zhang, L.P.; Li, Q.Y.; Han, W.Y. RBOH1-Dependent Apoplastic H 2 O 2 Mediates Epigallocatechin-3-Gallate-Induced Abiotic Stress Tolerance in Solanum Lycopersicum L. Environ. Exp. Bot. 2019, 161, 357-366. [CrossRef]

22. Greco, M.; Chiappetta, A.; Bruno, L.; Bitonti, M.B. In Posidonia Oceanica Cadmium Induces Changes in DNA Methylation and Chromatin Patterning. J. Exp. Bot. 2012, 63, 695-709. [CrossRef] [PubMed]

23. Zhao, C.; Zhang, H.; Song, C.; Zhu, J.K.; Shabala, S. Mechanisms of Plant Responses and Adaptation to Soil Salinity. Innovation 2020, 1, 100017. [CrossRef] [PubMed]

24. Golldack, D.; Li, C.; Mohan, H.; Probst, N. Tolerance to Drought and Salt Stress in Plants: Unraveling the Signaling Networks. Front. Plant Sci. 2014, 5, 1-10. [CrossRef]

25. Cebrián, G.; Iglesias-Moya, J.; García, A.; Martínez, J.; Romero, J.; Regalado, J.J.; Martínez, C.; Valenzuela, J.L.; Jamilena, M. Involvement of Ethylene Receptors in the Salt Tolerance Response of Cucurbita Pepo. Hortic. Res. 2021, 8, 1-14. [CrossRef]

26. Verma, R.K.; Santosh Kumar, V.V.; Yadav, S.K.; Pushkar, S.; Rao, M.V.; Chinnusamy, V. Overexpression of ABA Receptor PYL10 Gene Confers Drought and Cold Tolerance to Indica Rice. Front. Plant Sci. 2019, 10, 1-16. [CrossRef]

27. van Zelm, E.; Zhang, Y.; Testerink, C. Salt Tolerance Mechanisms of Plants. Ann. Rev. Plant Biol. 2020, 71, 403-433. [CrossRef]

28. Kumar, S.; Beena, A.S.; Awana, M.; Singh, A. Physiological, Biochemical, Epigenetic and Molecular Analyses of Wheat (Triticum aestivum) Genotypes with Contrasting Salt Tolerance. Front. Plant Sci. 2017, 8, 1-20. [CrossRef]

29. Neelam, S.; Subramanyam, R. Alteration of Photochemistry and Protein Degradation of Photosystem II from Chlamydomonas Reinhardtii under High Salt Grown Cells. J. Photochem. Photobiol. B Biol. 2013, 124, 63-70. [CrossRef]

30. Rasool, S.; Ahmad, A.; Siddiqi, T.O.; Ahmad, P. Changes in Growth, Lipid Peroxidation and Some Key Antioxidant Enzymes in Chickpea Genotypes under Salt Stress. Acta Physiol. Plant. 2013, 35, 1039-1050. [CrossRef]

31. Taffouo, V.D.; Nouck, A.H.; Dibong, S.D.; Amougou, A. Effects of Salinity Stress on Seedlings Growth, Mineral Nutrients and Total Chlorophyll of Some Tomato (Lycopersicum Esculentum L.) Cultivars. Afr. J. Biotechnol. 2010, 9, 5366-5372. [CrossRef]

32. Chen, Y.E.; Mao, J.J.; Sun, L.Q.; Huang, B.; Ding, C.B.; Gu, Y.; Liao, J.Q.; Hu, C.; Zhang, Z.W.; Yuan, S.; et al. Exogenous Melatonin Enhances Salt Stress Tolerance in Maize Seedlings by Improving Antioxidant and Photosynthetic Capacity. Physiol. Plant. 2018, 164, 349-363. [CrossRef] [PubMed]

33. Cramer, G.R.; Ergül, A.; Grimplet, J.; Tillett, R.L.; Tattersall, E.A.R.; Bohlman, M.C.; Vincent, D.; Sonderegger, J.; Evans, J.; Osborne, C.; et al. Water and Salinity Stress in Grapevines: Early and Late Changes in Transcript and Metabolite Profiles. Funct. Integr. Genom. 2007, 7, 111-134. [CrossRef] [PubMed]

34. Kongsri, S.; Boonprakob, U.; Byrne, D.H. Assessment of Morphological and Physiological Responses of Peach Rootstocks under Drought and Aluminum Stress. Acta Hortic. 2014, 1059, 229-236. [CrossRef]

35. Maggio, A.; Raimondi, G.; Martino, A.; De Pascale, S. Salt Stress Response in Tomato beyond the Salinity Tolerance Threshold. Environ. Exp. Bot. 2007, 59, 276-282. [CrossRef]

36. Ahmad, P.; Abd Allah, E.F.; Alyemeni, M.N.; Wijaya, L.; Alam, P.; Bhardwaj, R.; Siddique, K.H.M. Exogenous Application of Calcium to 24-Epibrassinosteroid Pre-Treated Tomato Seedlings Mitigates NaCl Toxicity by Modifying Ascorbate-Glutathione Cycle and Secondary Metabolites. Sci. Rep. 2018, 8, 13515. [CrossRef] [PubMed]

37. Sairam, R.K.; Rao, K.; Srivastava, G.C. Differential Response of Wheat Genotypes to Long Term Salinity Stress in Relation to Oxidative Stress, Antioxidant Activity and Osmolyte Concentration. Plant Sci. 2002, 163, 1037-1046. [CrossRef]

38. Miransari, M. Use of Microbes for the Alleviation of Soil Stresses: Volume 2: Alleviation of Soil Stress by Pgpr and Mycorrhizal Fungi; Springer: New York, NY, USA, 2014; pp. 1-184. [CrossRef]

39. Ashraf, M.; Foolad, M.R. Roles of Glycine Betaine and Proline in Improving Plant Abiotic Stress Resistance. Environ. Exp. Bot. 2007, 59, 206-216. [CrossRef]

40. Ahmad, P.; Latef, A.A.A.; Hashem, A.; Abd Allah, E.F.; Gucel, S.; Tran, L.S.P. Nitric Oxide Mitigates Salt Stress by Regulating Levels of Osmolytes and Antioxidant Enzymes in Chickpea. Front. Plant Sci. 2016, 7, 1-11. [CrossRef] [PubMed]

41. Sarker, U.; Oba, S. The Response of Salinity Stress-Induced A. tricolor to Growth, Anatomy, Physiology, Non-Enzymatic and Enzymatic Antioxidants. Front. Plant Sci. 2020, 11, 1-14. [CrossRef] [PubMed] 
42. Jahan, M.S.; Shu, S.; Wang, Y.; Chen, Z.; He, M.; Tao, M.; Sun, J. Melatonin Alleviates Heat-Induced Damage of Tomato Seedlings by Balancing Redox Homeostasis and Modulating Polyamine and Nitric Oxide Biosynthesis. BMC Plant Biol. 2019, $19,1-16$. [CrossRef] [PubMed]

43. Feng, Y.; Chen, X.; He, Y.; Kou, X.; Xue, Z. Effects of Exogenous Trehalose on the Metabolism of Sugar and Abscisic Acid in Tomato Seedlings Under Salt Stress. Trans. Tianjin Univ. 2019, 25, 451-471. [CrossRef]

44. Rahman, A.; Nahar, K.; Hasanuzzaman, M.; Fujita, M. Calcium Supplementation Improves $\mathrm{Na}^{+} / \mathrm{K}^{+}$Ratio, Antioxidant Defense and Glyoxalase Systems in Salt-Stressed Rice Seedlings. Front. Plant Sci. 2016, 7, 1-16. [CrossRef] [PubMed]

45. Queirós, F.; Rodrigues, J.A.; Almeida, J.M.; Almeida, D.P.F.; Fidalgo, F. Differential Responses of the Antioxidant Defence System and Ultrastructure in a Salt-Adapted Potato Cell Line. Plant Physiol. Biochem. 2011, 49, 1410-1419. [CrossRef]

46. Nahar, K.; Hasanuzzaman, M.; Alam, M.M.; Rahman, A.; Suzuki, T.; Fujita, M. Polyamine and Nitric Oxide Crosstalk: Antagonistic Effects on Cadmium Toxicity in Mung Bean Plants through Upregulating the Metal Detoxification, Antioxidant Defense and Methylglyoxal Detoxification Systems. Ecotoxicol. Environ. Saf. 2016, 126, 245-255. [CrossRef]

47. De Lacerda, C.F.; Cambraia, J.; Oliva, M.A.; Ruiz, H.A. Changes in Growth and in Solute Concentrations in Sorghum Leaves and Roots during Salt Stress Recovery. Environ. Exp. Bot. 2005, 54, 69-76. [CrossRef]

48. Rahneshan, Z.; Nasibi, F.; Moghadam, A.A. Effects of Salinity Stress on Some Growth, Physiological, Biochemical Parameters and Nutrients in Two Pistachio (Pistacia vera L.) Rootstocks. J. Plant Interact. 2018, 13, 73-82. [CrossRef]

49. Lekshmy, S.; Sairam, R.K.; Kushwaha, S.R. Effect of Long-Term Salinity Stress on Growth and Nutrient Uptake in Contrasting Wheat Genotypes. Ind. J. Plant Physiol. 2013, 18, 344-353. [CrossRef]

50. Manishankar, P.; Wang, N.; Köster, P.; Alatar, A.A.; Kudla, J. Calcium Signaling during Salt Stress and in the Regulation of Ion Homeostasis. J. Exp. Bot. 2018, 69, 4215-4226. [CrossRef]

51. Liu, Z.; Zhu, J.; Yang, X.; Wu, H.; Wei, Q.; Wei, H.; Zhang, H. Growth Performance, Organ-Level Ionic Relations and Organic Osmoregulation of Elaeagnus Angustifolia in Response to Salt Stress. PLoS ONE 2018, 13, e0191552. [CrossRef]

52. Gharsallah, C.; Fakhfakh, H.; Grubb, D.; Gorsane, F. Effect of Salt Stress on Ion Concentration, Proline Content, Antioxidant Enzyme Activities and Gene Expression in Tomato Cultivars. AoB Plants 2016, 8, 7-12. [CrossRef] [PubMed]

53. Muchate, N.S.; Rajurkar, N.S.; Suprasanna, P.; Nikam, T.D. NaCl Induced Salt Adaptive Changes and Enhanced Accumulation of 20-Hydroxyecdysone in the in Vitro Shoot Cultures of Spinacia oleracea (L.). Sci. Rep. 2019, 9, 12522. [CrossRef] [PubMed]

54. Koksal, N.; Alkan-Torun, A.; Kulahlioglu, I.; Ertargin, E.; Karalar, E. Ion Uptake of Marigold under Saline Growth Conditions. SpringerPlus 2016, 5, 1-12. [CrossRef] [PubMed]

55. Ahmad, P.; Ahanger, M.A.; Egamberdieva, D.; Alam, P.; Alyemeni, M.N.; Ashraf, M. Modification of Osmolytes and Antioxidant Enzymes by 24-Epibrassinolide in Chickpea Seedlings under Mercury (Hg) Toxicity. J. Plant Growth Regul. 2018, 37, 309-322. [CrossRef]

56. Hasanuzzaman, M.; Alam, M.M.; Rahman, A.; Hasanuzzaman, M.; Nahar, K.; Fujita, M. Exogenous Proline and Glycine Betaine Mediated Upregulation of Antioxidant Defense and Glyoxalase Systems Provides Better Protection against Salt-Induced Oxidative Stress in Two Rice (Oryza sativa L.) Varieties. BioMed Res. Int. 2014, 2014, 1-17. [CrossRef] [PubMed]

57. Li, X.; Zhong, Y.; Pang, X.; Yuan, Y.; Liu, Y.; Zhang, Z. Trypsin and Ascorbic Acid Have a Synergistic Effect on the Quality of Apple Processing by Protecting Apple Cells from Oxidative Damage. J. Food Biochem. 2018, 42, 1-7. [CrossRef]

58. Carvalho, L.C.; Vidigal, P.; Amâncio, S. Oxidative Stress Homeostasis in Grapevine (Vitis vinifera L.). Front. Environ. Sci. 2015, 3 , 1-15. [CrossRef]

59. Hsu, S.Y.; Wang, J.Y.; Liao, H.E. Factors Which Influence the Willingness of Injection Drug Users to Participate in the Harm Reduction Program. Taiwan J. Public Health 2007, 26, 292-302.

60. Ahmad, P.; Abdel Latef, A.A.; Abd-Allah, E.F.; Hashem, A.; Sarwat, M.; Anjum, N.A.; Gucel, S. Calcium and Potassium Supplementation Enhanced Growth, Osmolyte Secondary Metabolite Production, and Enzymatic Antioxidant Machinery in Cadmium-Exposed Chickpea (Cicer arietinum L.). Front. Plant Sci. 2016, 7, 1-12. [CrossRef]

61. Mishra, P.; Bhoomika, K.; Dubey, R.S. Differential Responses of Antioxidative Defense System to Prolonged Salinity Stress in Salt-Tolerant and Salt-Sensitive Indica Rice (Oryza sativa L.) Seedlings. Protoplasma 2013, 250, 3-19. [CrossRef]

62. Ahmad, P.; Hashem, A.; Abd-Allah, E.F.; Alqarawi, A.A.; John, R.; Egamberdieva, D.; Gucel, S. Role of Trichoderma Harzianum in Mitigating $\mathrm{NaCl}$ Stress in Indian Mustard (Brassica juncea L.) through Antioxidative Defense System. Front. Plant Sci. 2015, 6 , 1-15. [CrossRef] [PubMed]

63. Fatma, M.; Masood, A.; Per, T.S.; Khan, N.A. Nitric Oxide Alleviates Salt Stress Inhibited Photosynthetic Performance by Interacting with Sulfur Assimilation in Mustard. Front. Plant Sci. 2016, 7, 521. [CrossRef] [PubMed]

64. Ali, Q.; Daud, M.K.; Haider, M.Z.; Ali, S.; Rizwan, M.; Aslam, N.; Noman, A.; Iqbal, N.; Shahzad, F.; Deeba, F.; et al. Seed Priming by Sodium Nitroprusside Improves Salt Tolerance in Wheat (Triticum aestivum L.) by Enhancing Physiological and Biochemical Parameters. Plant Physiol. Biochem. 2017, 119, 50-58. [CrossRef] [PubMed]

65. Foyer, C.H.; Noctor, G. Ascorbate and Glutathione: The Heart of the Redox Hub. Plant Physiol. 2011, 155, 2-18. [CrossRef]

66. Dixit, G.; Singh, A.P.; Kumar, A.; Singh, P.K.; Kumar, S.; Dwivedi, S.; Trivedi, P.K.; Pandey, V.; Norton, G.J.; Dhankher, O.P.; et al. Sulfur Mediated Reduction of Arsenic Toxicity Involves Efficient Thiol Metabolism and the Antioxidant Defense System in Rice. J. Hazard. Mater. 2015, 298, 241-251. [CrossRef] 
67. Kaur, H.; Sirhindi, G.; Bhardwaj, R.; Alyemeni, M.N.; Kadambot, H.M. 28-Homobrassinolide Regulates Antioxidant Enzyme Activities and Gene Expression in Response to Salt- and Temperature-Induced Oxidative Stress in Brassica juncea. Sci. Rep. 2018, 8, 8735. [CrossRef]

68. Mazorra, L.M.; Oliveira, M.G.; Souza, A.F.; da Silva, W.B.; dos Santos, G.M.; da Silva, L.R.A.; Bartoli, C.G.; de Oliveira, J.G. Involvement of brassinosteroids and ethylene in the control of mitochondrial electron transport chain in postharvest papaya fruit. Theor. Exp. Plant Physiol. 2013, 25, 203-212. [CrossRef]

69. Hu, X.; Zhang, Y.; Shi, Y.; Zhang, Z.; Zou, Z.; Zhang, H.; Zhao, J. Effect of Exogenous Spermidine on Polyamine Content and Metabolism in Tomato Exposed to Salinity-Alkalinity Mixed Stress. Plant Physiol. Biochem. 2012, 57, 200-209. [CrossRef]

70. Li, S.; Jin, H.; Zhang, Q. The Effect of Exogenous Spermidine Concentration on Polyamine Metabolism and Salt Tolerance in Zoysiagrass (Zoysia japonica Steud) Subjected to Short-Term Salinity Stress. Front. Plant Sci. 2016, 7, 1221. [CrossRef]

71. Liu, J.-H.; Wang, W.; Wu, H.; Gong, X.; Moriguchi, T. Polyamines Function in Stress Tolerance: From Synthesis to Regulation. Front. Plant Sci. 2015, 6, 1-10. [CrossRef]

72. Kwak, J.M.; Mori, I.C.; Pei, Z.M.; Leonhard, N.; Angel Torres, M.; Dangl, J.L.; Bloom, R.E.; Bodde, S.; Jones, J.D.G.; Schroeder, J.I. NADPH Oxidase AtrbohD and AtrbohF Genes Function in ROS-Dependent ABA Signaling in Arabidopsis. EMBO J. 2003, 22, 2623-2633. [CrossRef] [PubMed]

73. Sirichandra, C.; Gu, D.; Hu, H.C.; Davanture, M.; Lee, S.; Djaoui, M.; Valot, B.; Zivy, M.; Leung, J.; Merlot, S.; et al. Phosphorylation of the Arabidopsis AtrbohF NADPH Oxidase by OST1 Protein Kinase. FEBS Lett. 2009, 583, 2982-2986. [CrossRef] [PubMed]

74. Liu, T.; Hu, X.; Zhang, J.; Zhang, J.; Du, Q.; Li, J. $\mathrm{H}_{2} \mathrm{O}_{2}$ Mediates ALA-Induced Glutathione and Ascorbate Accumulation in the Perception and Resistance to Oxidative Stress in Solanum Lycopersicum at Low Temperatures. BMC Plant Biol. 2018, 18, 1-10. [CrossRef] [PubMed]

75. Xu, J.; Yang, J.; Xu, Z.; Zhao, D.; Hu, X. Exogenous Spermine-Induced Expression of SISPMS Gene Improves Salinity-Alkalinity Stress Tolerance by Regulating the Antioxidant Enzyme System and Ion Homeostasis in Tomato. Plant Physiol. Biochem. 2020, 157, 79-92. [CrossRef] [PubMed]

76. Zhou, J.; Xia, X.J.; Zhou, Y.H.; Shi, K.; Chen, Z.; Yu, J.Q. RBOH1 -Dependent $\mathrm{H}_{2} \mathrm{O}_{2}$ Production and Subsequent Activation of MPK1/2 Play an Important Role in Acclimation-Induced Cross-Tolerance in Tomato. J. Exp. Bot. 2014, 65, 595-607. [CrossRef] [PubMed]

77. Ma, L.; Zhang, H.; Sun, L.; Jiao, Y.; Zhang, G.; Miao, C.; Hao, F. NADPH Oxidase AtrbohD and AtrbohF Function in ROSDependent Regulation of $\mathrm{Na}^{+} / \mathrm{K}^{+}$Homeostasis in Arabidopsis under Salt Stress. J. Exp. Bot. 2012, 63, 305-317. [CrossRef] [PubMed]

78. Raghavendra, A.S.; Gonugunta, V.K.; Christmann, A.; Grill, E. ABA Perception and Signalling. Trends Plant Sci. 2010, 15, 395-401. [CrossRef]

79. Zhao, S.; Zhang, Q.; Liu, M.; Zhou, H.; Ma, C.; Wang, P. Regulation of Plant Responses to Salt Stress. Int. J. Mol. Sci. 2021, 22, 4609. [CrossRef]

80. Tuteja, N. Mechanisms of High Salinity Tolerance in Plants. Methods Enzymol. 2007, 428, 419-438. [CrossRef]

81. Frey, A.; Effroy, D.; Lefebvre, V.; Seo, M.; Perreau, F.; Berger, A.; Sechet, J.; To, A.; North, H.M.; Marion-Poll, A. Epoxycarotenoid Cleavage by NCED5 Fine-Tunes ABA Accumulation and Affects Seed Dormancy and Drought Tolerance with Other NCED Family Members. Plant J. 2012, 70, 501-512. [CrossRef]

82. Ijaz, R.; Ejaz, J.; Gao, S.; Liu, T.; Imtiaz, M.; Ye, Z.; Wang, T. Overexpression of Annexin Gene AnnSp2, Enhances Drought and Salt Tolerance through Modulation of ABA Synthesis and Scavenging ROS in Tomato. Sci. Rep. 2017, 7, 12087. [CrossRef] [PubMed]

83. Huang, Y.; Guo, Y.; Liu, Y.; Zhang, F.; Wang, Z.; Wang, H.; Wang, F.; Li, D.; Mao, D.; Luan, S.; et al. 9-Cis-Epoxycarotenoid Dioxygenase 3 Regulates Plant Growth and Enhances Multi-Abiotic Stress Tolerance in Rice. Front. Plant Sci. $2018,9,162$. [CrossRef] [PubMed]

84. Xiong, L.; Zhu, J.K. Regulation of Abscisic Acid Biosynthesis. Plant Physiol. 2003, 133, 29-36. [CrossRef] [PubMed]

85. Park, H.Y.; Seok, H.Y.; Park, B.K.; Kim, S.H.; Goh, C.H.; Lee, B.; Lee, C.H.; Moon, Y.H. Overexpression of Arabidopsis ZEP Enhances Tolerance to Osmotic Stress. Biochem. Biophys. Res. Commun. 2008, 375, 80-85. [CrossRef]

86. Diaz-Vivancos, P.; Barba-Espín, G.; Hernández, J.A. Elucidating Hormonal/ROS Networks during Seed Germination: Insights and Perspectives. Plant Cell Rep. 2013, 32, 1491-1502. [CrossRef]

87. Song, X.; Yu, X.; Hori, C.; Demura, T.; Ohtani, M.; Zhuge, Q. Heterologous Overexpression of Poplar Snrk2 Genes Enhanced Salt Stress Tolerance in Arabidopsis thaliana. Front. Plant Sci. 2016, 7, 1-11. [CrossRef]

88. Jurkiewicz, P.; Batoko, H. Protein Degradation Mechanisms Modulate Abscisic Acid Signaling and Responses during Abiotic Stress. Plant Sci. 2018, 267, 48-54. [CrossRef]

89. de Zelicourt, A.; Colcombet, J.; Hirt, H. The Role of MAPK Modules and ABA during Abiotic Stress Signaling. Trends Plant Sci. 2016, 21, 677-685. [CrossRef]

90. Arbona, V.; Zandalinas, S.I.; Manzi, M.; González-Guzmán, M.; Rodriguez, P.L.; Gómez-Cadenas, A. Depletion of Abscisic Acid Levels in Roots of Flooded Carrizo Citrange (Poncirus trifoliata L. Raf. $\times$ Citrus sinensis L. Osb.) Plants Is a Stress-Specific Response Associated to the Differential Expression of PYR/PYL/RCAR Receptors. Plant Mol. Biol. 2017, 93, 623-640. [CrossRef]

91. Fujii, H.; Verslues, P.E.; Zhu, J.K. Identification of Two Protein Kinases Required for Abscisic Acid Regulation of Seed Germination, Root Growth, and Gene Expression in Arabidopsis. Plant Cell 2007, 19, 485-494. [CrossRef] 
92. Shukla, M.R.; Bajwa, V.S.; Freixas-Coutin, J.A.; Saxena, P.K. Salt Stress in Arabidopsis thaliana Seedlings: Role of Indoleamines in Stress Alleviation. Melatonin Res. 2021, 4, 70-83. [CrossRef]

93. Yoshida, T.; Fujita, Y.; Maruyama, K.; Mogami, J.; Todaka, D.; Shinozaki, K.; Yamaguchi-Shinozaki, K. Four Arabidopsis AREB/ABF Transcription Factors Function Predominantly in Gene Expression Downstream of SnRK2 Kinases in Abscisic Acid Signalling in Response to Osmotic Stress. Plant Cell Environ. 2015, 38, 35-49. [CrossRef] [PubMed]

94. Wang, W.R.; Liang, J.H.; Wang, G.F.; Sun, M.X.; Peng, F.T.; Xiao, Y.S. Overexpression of PpSnRK1 $\alpha$ in Tomato Enhanced Salt Tolerance by Regulating ABA Signaling Pathway and Reactive Oxygen Metabolism. BMC Plant Biol. 2020, 20, 1-15. [CrossRef] [PubMed]

95. Fujita, Y.; Fujita, M.; Satoh, R.; Maruyama, K.; Parvez, M.M.; Seki, M.; Hiratsu, K.; Ohme-Takagi, M.; Shinozaki, K.; YamaguchiShinozaki, K. AREB1 Is a Transcription Activator of Novel ABRE-Dependent ABA Signaling That Enhances Drought Stress Tolerance in Arabidopsis. Plant Cell 2005, 17, 3470-3488. [CrossRef] [PubMed]

96. Hichri, I.; Muhovski, Y.; Clippe, A.; Žižková, E.; Dobrev, P.I.; Motyka, V.; Lutts, S. SIDREB2, a Tomato Dehydration-Responsive Element-Binding 2 Transcription Factor, Mediates Salt Stress Tolerance in Tomato and Arabidopsis. Plant Cell Environ. 2016, 39 62-79. [CrossRef] [PubMed]

97. Chan, Z. Expression Profiling of ABA Pathway Transcripts Indicates Crosstalk between Abiotic and Biotic Stress Responses in Arabidopsis. Genomics 2012, 100, 110-115. [CrossRef]

98. Tao, J.J.; Wei, W.; Pan, W.J.; Lu, L.; Li, Q.T.; Ma, J.B.; Zhang, W.K.; Ma, B.; Chen, S.Y.; Zhang, J.S. An Alfin-like Gene from Atriplex Hortensis Enhances Salt and Drought Tolerance and Abscisic Acid Response in Transgenic Arabidopsis. Sci. Rep. 2018, 8, 2707. [CrossRef]

99. Kadoglidou, K.; Xanthopoulou, A.; Kalyvas, A.; Mellidou, I. Utilization of Tomato Landraces to Improve Seedling Performance under Salt Stress. Stresses 2021, 1, 238-252. [CrossRef]

100. Mulholland, B.J.; Taylor, I.B.; Jackson, A.C.; Thompson, A.J. Can ABA Mediate Responses of Salinity Stressed Tomato. Environ. Exp. Bot. 2003, 50, 17-28. [CrossRef]

101. González, L.; González-Vilar, M. Determination of Relative Water Content. In Handbook of Plant Ecophysiology Techniques; Reigosa Roger, M.J., Ed.; Springer: Dordrecht, The Netherlands, 2001. [CrossRef]

102. Morgan, J.A. Interaction of Water Supply and N in Wheat. Plant Physiol. 1984, 76, 112-117. [CrossRef] [PubMed]

103. Lichtenthaler, H.K. Chlorophylls and Carotenoids: Pigments of Photosynthetic Biomembranes. Methods Enzymol. 1987, 148, 350-382. [CrossRef]

104. Arnon, D.I. Copper Enzymes in Isolated Chloroplasts. Polyphenoloxidase in Beta vulgaris. Plant Physiol. 1949, 24, 1-15. [CrossRef] [PubMed]

105. Han, Y.; Jiang, J.; Liu, H.; Ma, Q.; Xu, W.; Xu, Y.; Xu, Z.; Chong, K. Overexpression of OsSIN, Encoding a Novel Small Protein, Causes Short Internodes in Oryza sativa. Plant Sci. 2005, 169, 487-495. [CrossRef]

106. Jiang, D.; Lu, B.; Liu, L.; Duan, W.; Chen, L.; Li, J. Exogenous Melatonin Improves Salt Stress Adaptation of Cotton Seedlings by Regulating Active Oxygen Metabolism. PeerJ 2020, 8, e10486. [CrossRef]

107. Rapid Determination of Free Proline for Water-Stress Studies. Plant Soil 1973, 39, 205-207. [CrossRef]

108. Niu, M.; Huang, Y.; Sun, S.; Sun, J.; Cao, H.; Shabala, S.; Bie, Z. Root Respiratory Burst Oxidase Homologue-Dependent $\mathrm{H}_{2} \mathrm{O}_{2}$ Production Confers Salt Tolerance on a Grafted Cucumber by Controlling $\mathrm{Na}^{+}$Exclusion and Stomatal Closure. J. Exp. Bot. 2018, 69, 3465-3476. [CrossRef]

109. Zhang, Y.; Liang, Y.; Zhao, X.; Jin, X.; Hou, L.; Shi, Y.; Ahammed, G.J. Silicon Compensates Phosphorus Deficit-Induced Growth Inhibition by Improving Photosynthetic Capacity, Antioxidant Potential, and Nutrient Homeostasis in Tomato. Agronomy 2019, 9, 733. [CrossRef]

110. Hayat, S.; Hasan, S.A.; Yusuf, M.; Hayat, Q.; Ahmad, A. Effect of 28-Homobrassinolide on Photosynthesis, Fluorescence and Antioxidant System in the Presence or Absence of Salinity and Temperature in Vigna Radiata. Environ. Exp. Bot. 2010, 69, 105-112 [CrossRef]

111. Jahan, M.S.; Guo, S.; Baloch, A.R.; Sun, J.; Shu, S.; Wang, Y.; Ahammed, G.J.; Kabir, K.; Roy, R. Melatonin Alleviates Nickel Phytotoxicity by Improving Photosynthesis, Secondary Metabolism and Oxidative Stress Tolerance in Tomato Seedlings. Ecotoxicol. Environ. Saf. 2020, 197, 110593. [CrossRef]

112. Lu, C.; Qiu, N.; Wang, B.; Zhang, J. Salinity Treatment Shows No Effects on Photosystem II Photochemistry, but Increases the Resistance of Photosystem II to Heat Stress in Halophyte Suaeda Salsa. J. Exp. Bot. 2003, 54, 851-860. [CrossRef]

113. Giannopolitis, C.N.; Ries, S.K. Superoxide Dismutases. Plant Physiol. 1977, 59, 309-314. [CrossRef] [PubMed]

114. Dhindsa, R.S.; Plumb-dhiiidsa, P.L.; Reid, D.M.; Leaf, D.M. Leaf Senescence and Lipid Peroxidation: Effects of Some Phytohormones, and Scavengers of Free Radicals and Singlet Oxygen. Physiol. Plant. 1982, 56, 453-457. [CrossRef]

115. Aebi, H. Catalase in vitro. Methods Enzymol. 1984, 105, 121-126. [PubMed]

116. Nakano, Y.; Asada, K. Hydrogen Peroxide Is Scavenged by Ascorbate-Specific Peroxidase in Spinach Chloroplasts. Plant Cell Physiol. 2018, 22, 867-880.

117. Hossain, M.A.; Nakano, Y.; Asada, K. Monodehydroascorbate Reductase in Spinach Chloroplasts and Its Participation in Regeneration of Ascorbate for Scavenging Hydrogen Peroxide. Plant Cell Physiol. 1984, 25, 385-395. [CrossRef]

118. Logan, B.A.; Demmig-Adams, B.; Adams, W.W.; Grace, S.C. Antioxidants and Xanthophyll Cycle-Dependent Energy Dissipation in Cucurbita pepo L. and Vinca major L. Acclimated to Four Growth PPFDs in the Field. J. Exp. Bot. 1998, 49, 1869-1879. [CrossRef] 
119. Kranner, I.; Birtić, S.; Anderson, K.M.; Pritchard, H.W. Glutathione Half-Cell Reduction Potential: A Universal Stress Marker and Modulator of Programmed Cell Death? Free Radic. Biol. Med. 2006, 40, 2155-2165. [CrossRef]

120. Griffith, O.W.; Meister, A. Origin and turnover of mitochondrial glutathione. Proc. Natl. Acad. Sci. USA 1985, 82, 4668-4672. [CrossRef] [PubMed]

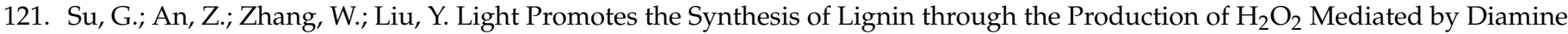
Oxidases in Soybean Hypocotyls. J. Plant Physiol. 2005, 162, 1297-1303. [CrossRef]

122. Walker-Simmons, M. ABA Levels and Sensitivity in Developing Wheat Embryos of Sprouting Resistant and Susceptible Cultivars. Plant Physiol. 1987, 84, 61-66. [CrossRef]

123. Weiler, E.W. Radioimmunoassays for the Differential and Direct Analysis of Free and Conjugated Abscisic Acid in Plant Extracts. Planta 1980, 148, 262-272. [CrossRef] [PubMed]

124. Norman, S.M.; Poling, S.M.; Maier, V.P. An Indirect Enzyme-Linked Immunosorbent Assay for $\left(^{+}\right)$-Abscisic Acid in Citrus, Ricinus, and Xanthium Leaves. J. Agric. Food Chem. 1988, 36, 225-231. [CrossRef]

125. Zhang, Y.; Wang, Y.; Wen, W.; Shi, Z.; Gu, Q.; Ahammed, G.J.; Cao, K.; Shah Jahan, M.; Shu, S.; Wang, J.; et al. Hydrogen Peroxide Mediates Spermidine-Induced Autophagy to Alleviate Salt Stress in Cucumber. Autophagy 2021, 17, 2876-2890. [CrossRef] [PubMed] 